\title{
GEOGRAPHICAL D'STRIBUTION
}

\author{
OF \\ BRITISH BIRDS.
}

BY

HENRY SEEBOHM.

\section{LON DON:}

R. H. PORTER, 18 PRINCES STREET, CAVENDTSH SQUARE, W. 1893.

[Price 7s.6d. net.] 



\section{GEOGRAPHICAL DISTRIBUTION}

OF

\section{BRITISH BIRDS.}

BY

HENRY SEEBOHM.

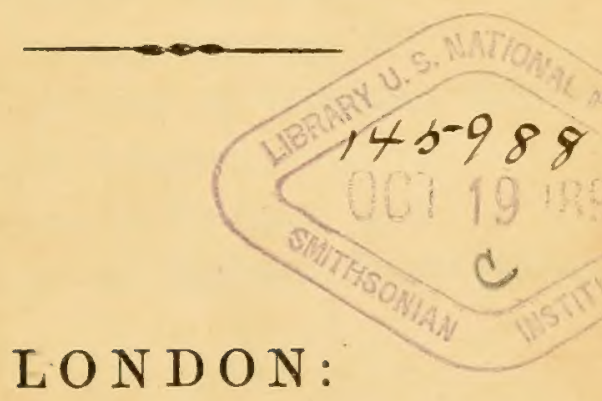

R. H. PORTER, 18 PRINCES STREET, CAVENDISH SQUARE, W. 


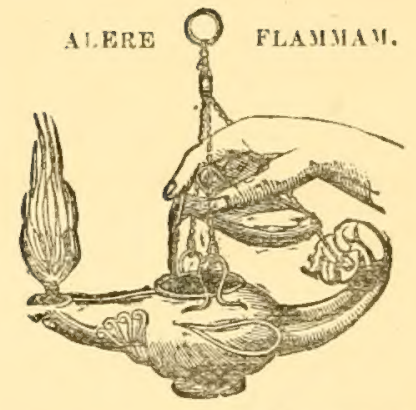

PRINTED BY TAYLOR $\triangle$ ND FRANCIS, RED LION CONRT, FLEET STREET. 


\section{CONTENTS.}

Page

Preface

INTRODUCtory Remarks - . . . . . . . . . . . . . . 1

Supposed Accidental Visitors . . . . . . . . . . . 2

Introduced Species . . . . . . . . . . . . . . . 3

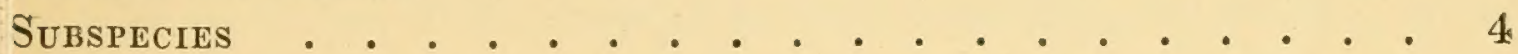

Geographical Distribution of Birds within the British Islands. 4

Residents . • . • . • . . • . • . . 6

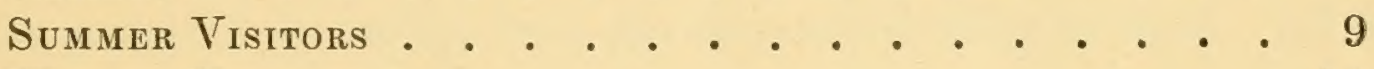

Winter Visitors . . . • . . . . • . • . . 11

Spring and Autumn Migrants . • . . . . . . . 13

Accidental Visitors . • . • • • • • • • • . . 15

Jeographical Distribution of British Birds during the BreedingSeason outside the British Islands . • • . . . . . . 19

Circumpolar and Circumtropic Species . . . . . . 20

Nearly Circumpolar Spectes . . . . . . . . . . 22

North Atlantic Species . . . . . . . . . . . 23

Nearctic Spectes . . . . . . . . . . . . 24

Palearctic Species . . . . . . . . . . . . . 25

West Palanctic Species . . . . . . . . . . 29

Species Ranging East to $110^{\circ}$ • . . . . . . . 29

SPECIES RANGING EAST to $85^{\circ}$ • . . . . . . . 30

SPECIES RANGING EAST to $70^{\circ}$. . . . . . . . . 32

Species Ranging east to $60^{\circ}$. • • . . . . . . 33

SPECIES RANGING EAST TO $50^{\circ}$. . . . . . . . 34

Species confined to Western Europe . . . . . 35

East Palearctic Species . . . . . . . . . 35

Centhal Palfearctic Species . . . . . . . . . 36

Ylimatic Distribution of British Birds during the BreedingSEASON . . . . . . . . . . . . . . 37

IPPENDIX: Brief Summary of the Geographical Distribution of kach Britist Brrd, \&c. . . . . . . . . . . . 41 



\section{PREFACE.}

The following attempt to make some amends to the Members of the British Ornithologists' Union for the thousand and one blunders contained in a list of British Birds compiled by their committee, for which I, as one of the seven delinquents, must bear my share of responsibility and blame, does not pretend to be exempt from the universal liability to error. All it can claim is that some pains have been taken to master the subject and to weigh the balance of evidence in each case as impartially as possible.

The attempt has been made to classify British Birds in three different ways. Firstly, as to their distribution within the British Islands ; secondly, as to their distribution during the breeding-season outside the British Islands; and thirdly, as to their climatic distribution during the breedingseason.

Finally, a list of British Birds has been added containing as much information respecting the geographical distribution of each species as could be compressed into four or five lines. This list is printed on one side of the paper only, so that it can be cut up and used as labels for collections of stuffed birds or eggs.

H. S. 



\title{
GEOGRAPHICAL DISTRIBUTION
}

\author{
OF

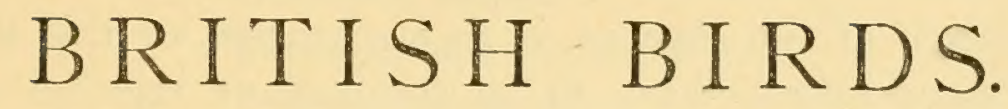

Introductory Remarks.

Geographical Distribution is a branch of the science of Zoology which has very greatly increased in interest since the theory of Evolution has been generally accepted. It was Darwin's opinion, which recent research has invariably confirmed, that without isolation the differentiation of species is impossible, and of all possible modes of Isolation, Geographical Isolation is the most important.

The number of species which have been included in the list of British Birds at various times considerably exceeds four hundred, but of these many have been admitted on most untrustworthy evidence.

The sources of error are various. In some cases a mistake has been made in the naming of the examples, in others the examples have been correctly named but they were not obtained in the British Islands, having been changed either by accident or by design by a careless or fraudulent birdstuffer, or by a collector ignorant of the value of scientific accuracy.

A third and very frequent source of error, which it is often impossible to avoid, is caused by the escape of imported birds from aviaries, or the attempts which have been from time to time made to introduce new species into this country by importing birds from abroad and turning them out in the most favourable localities. We may also include under this head the birds which are occasionally helped over the ocean by alighting on the rigging or frequently the decks of the ships which are always scattered over the high seas.

The greatest difficulty which presents itself, in attempting to estimate the number of visitors to our Islands, is to be found in the vagueness of the records of their supposed visits. These records display, for the most part, a lamentable want of knowledge of the nature and value of evidence. The mere statement that a certain bird was shot at a certain place on a 
certain day is not enough. The characters relied upon for the determination of the species should, in all cases, be stated. The condition of the plumage and the appearance of the feet should be noted, and any peculiarity of habit which might possibly throw any light upon the chances of the bird having escaped from confinement ought to be recorded. Every scrap of evidence to prove that the example was actually procured in this country in an apparently wild state, and was examined in the flesh by absolutely trustworthy witnesses, is of the greatest interest and scientific value.

In consequence of the absence, in so many cases, of this all-important evidence too many records have to be accepted or rejected on the most unsatisfactory ground-the supposed probability or improbability of the occurrence of the species recorded.

It seems to be gerierally admitted that birds which are ouly seen and not procured, however competent the observer, must be entirely excluded. The maxim of the "Old Bushman" that what is hit is history, but what is missed is mystery, must be rigidly enforced. Of birds that have only once been recorded as British the balance of probabilities must be weighed as best it may. The fact that the Siberian Thrush (Geocichla sibirica) has occurred at ten or more places in Europe increases the probability that the English record is a correct one. The circumstance that several species of Gallinules (Porphyrio) are kept in aviaries and on ornamental waters very much weakens the evidence in favour of any of them having visited the country in a wild state. Many examples of the Virginian Colin (Ortyx virginianus) and of the Andalucian Hemipode (Turnix sylvatica) have been turned out in the attempt to naturalize them in this country, and it is only reasonable to suppose that records of the capture of either of these species probably refer to imported birds or their descendants.

Some species are rejected on the ground of the inherent improbability of their ever having voluntarily paid a visit to our Islands, such as the Gold-vented Bulbul (Pycnonotus capensis), a species supposed to be absolutely confined to the extreme south of Africa. There can be no doubt that migratory birds are much more likely to visit us accidentally than those which are non-migratory; and it must also be admitted that most accidental visitors from America or Asia which have been caught in Europe are those which breed in the Arctic Regions, and have, consequently, to deviate less from their usual course in straying to our shores.

\section{Supposed Accidental Visitors.}

In a score of cases I have admitted the existence of some evidence in favour of a species having paid a voluntary visit to the British Islands by recording it as a supposed accidental visitor. It is impossible to say how 
much doubt ought to cause the complete rejection of a species, or what amount of evidence may justify its being admitted to the rank of a supposed visitor; but I have endeavonred to draw the line as fairly as possible, and have included the following species in this doubtful class.

Eleven of these are supposed to have visited our Islands from arctic or subarctic America-

Ceryle alcyon,

Agelaius phoniceus,

Sturnella magna,

Scolecophagus ferrugineus,

Progne purpurea,

Elanoides furcatus,

Falco sparverius,

Cygnus americanus,

Bernicla canadensis,

Anas americana,

Anas discors;

five from Central or Southern Europe-

Turnix sylvatica,

Phonicopterus roseus,

Porphyrio cceruleus,

Pyrrhocorax alpinus,

Fringilla serimus ;

one from East Siberia-

Emberiza cioides;

one from the Azores or Madeira-

Fringilla canaria ;

one from tropical India-

Falco juggur ;

one from tropical Africa-

Porphyrio smaragdonotus ;

and one from tropical America-

Porphyrio martinicus.

\section{Introduced Species.}

In addition to the doubtful species we may exclude one or two other specics which have been artificially introduced from more or less distant 
localities, and have therefore nothing to do with the geographical distribution of the Birds of any part of Western Europe-

Phasianus torquatus,

introduced from China, a species ranging from Dauria to the Pacific, and

Phasianus colchicus,

introduced from the basin of the Black Sea.

\section{Subspecies.}

After the exclusion of the doubtful species, and those which have been introduced from distant countries, there still remain 391 species and subspecies of birds which have a fair claim to be regarded as British; but of these there are thirtecn subspecies which appear to be local races or climatic forms of species which are already included in the British list, so that the number of species of British Birds is reduced to 378 . These subspecies are:-

Cinclus aquaticus melanogaster.

Parus ater britannicus.

Troglodytes parvulus hirtensis.

Corvus corone cornix.

Loxia curvirostra pityopsittacus.

Loxia leucoptera bifasciata.

Fringilla linaria rufescens.

Fringilla linaria hornemanni.

Surnia funerea hudsonia.

Falco gyrfalco islandus.

Falco gyrfalco candicans.

Charadrius fulvus americanus.

Charadrius hiaticula major.

Inasmuch, however, as all these subspecies have geographical ranges differing from those of the typical forms (otherwise they could not claim even subspecific rank) they must be regarded as sufficiently distinct to be separately mentioned.

Geographical Distribution of Birds within the British Islands.

The Geographical Distribution of British Birds may be studied from various points of view, and I propose in the first place to classify the 391 birds which have the greatest claim to be regarded as British according to the variation of their distribution within the British Islands.

Those species which are found in the British Islands both in winter and 
in summer are called Residents, though many of them migrate from one part of the country to another part in spring and autumn. Those birds which visit us in spring, remain with us during their breeding-season, but leave us again in autumn to winter in more southerly climes, are called Summer Visitors. Those which visit us in autumn, remain with us during the winter, but leave us again in spring to brecd in more northerly climes, are callcd Winter Visitors. A fourth group consists of species whose brecting-grounds are further north than the British Islands, and whose winter-quarters are further south, and which consequently are only found in our Islands for a few wcels during migration in spring and autumn. They are called Spring and Autumn Migrants.

The fifth group is a very large one and contains all those waifs and strays which are supposed to hare wandered out of thcir usual track to our shores, some of them being adult birds that have been driven involuntarily out of their ordinary course by storms and contrary winds, but most of them being very young lirds which liave accidentally joined the wrong batch of migrants, and have thus beeu led astray on their first trip, or hare lost their way in attempting to find it alone on their second trip. These are called Accidental Visitors.

It is impossible to draw a hard-and-fast line between these various groups, and it must frequently be a question of individual judgment to decide the exact group to which some species ought to be referred.

The Accidental Visitors blend, on the one hand, with the Winter Visitors, and on the other with the Summer Visitors. It is impossible to fix any number of records per year or per century that ought to entitle a species to be removed from the list of Accidental Visitors to those of occasional, very rare, rare, or regular Winter or Summer Visitors. Any line that is drawn between one group and another must of course be arbitrary, and subject also to change with the changed geographical distribution of the species. Many specics which can now only be regarded as accidental visitors to our Islands were regular Summer Visitors not a century ago; and some species which were regarded as accidental visitors a century ago appear to have recently extended the range of their breedinggrounds in a westerly direction, and occur so frequently upon our coasts in autumn that they may now be included in the list of Winter Visitor's. The Shore Lark and Richard's Pipit are cases in point.

The boundary-line between the Winter Visitors and the Residents is quite as difficult to draw. The number of Woodcocks which visit us in antumn is doubtless very largely in excess of the number which breed in this country; and great numbers of birds of the same species as many of our residents arrive from Scandinavia at various points on the east coast to winter here. Probably the number of more than half of our so-called resident species is increased by visitors from the Continent during the autumn migration. I have endeavoured to asccrtain in the various species 
which predominate the residents or the winter visitors, and to allot them accordingly.

It is obvious that some species may belong to one category in England, and to another in Scotland or Ireland. For example, the Dartford Warbler is a resident in England, but unknown in Scotland and Ireland; whilst the Ptarmigan is a resident in Scotland, but unknown in England or Ireland. In the following summary of the distribution of birds within the British Islands, the word partial is prefixed to those appellations which do not apply to all three kingdoms:-

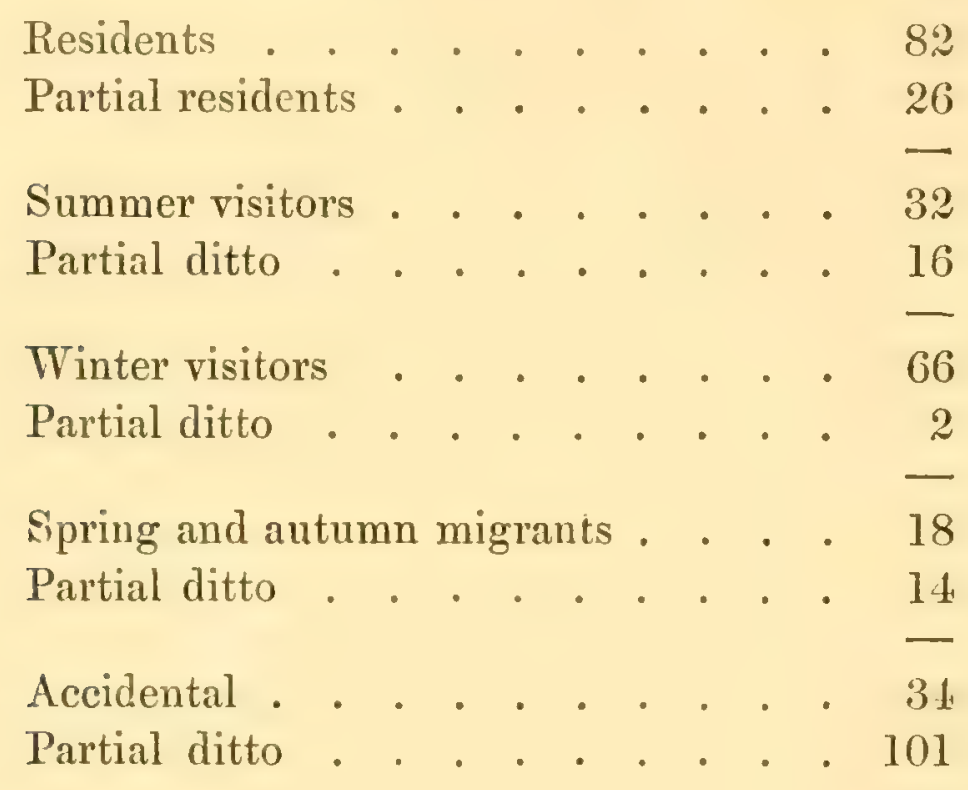

RESIDENTS.

Of the 108 species of British Birds which are most accurately described as Residents, 3 have not occurred in England, 3 are unknown in Scotland, whilst as many as 10 are not known to have visited Ireland.

The following species may be regarded as resideuts both in England, Scotland, and Ireland :-

Falco peregrinus.

Falco tinnunculus.

Falco resalon.

Buteo vulgaris.

Accipiter nisus.

Strix otus.

Aluco flammeus.

Corvus corax.

Corvus corone.

Corvus monedula.

Corvus frugilegus. 
Pyrrhocorax graculus.

Pica caudata.

Loxia curvirostra.

Pyrrhula vulgaris.

Fringilla chloris.

Fringilla flavirostris.

Fringilla cannabina.

Fringilla calebs.

Fringilla carduelis.

Fringilla linaria rufescens.

Passer domesticus.

Passer montanus.

Emberiza schœniclus.

Emberiza miliaria.

Emberiza citrinella.

Turdus viscivorus.

Turdus musicus.

Merula merula.

Erithacus rubecula.

Pratincola rubicola.

Accentor modularis.

Parus palustris.

Parus creruleus.

Parus ater britannicus.

Parus major.

Acredula rosea.

Troglodytes parvulus.

Regulus cristatus.

Certhia familiaris.

Motacilla boarula.

Motacilla yarrelli.

Anthus pratensis.

Anthus obscurus.

Alauda arvensis.

Alauda arborea.

Sturnus vulgaris.

Garrulus glandarius.

Cinclus aquaticus.

Alcedo ispida.

Columba livia.

Columba palumbus.

Columba anas.

Tetrao scoticus. 
Perdix cinerea.

Gallinula chloropus.

Fulica atra.

Rallus aquaticus.

Numenius arguata.

Vanellus cristatus.

Charadrius hiaticula major.

Tutanus calidris.

Scolopax gallinago.

Hematopus ostralegus.

Botaurus stellaris.

Ardea cinerea.

Sula bassana.

Phalacrocorax graculus.

Phalacrocorax carbo.

Puffinus anglorum.

Procellaria pelagica.

Alca torda.

Alca troile.

Podiceps cristatus.

Podiceps minor.

Cygnus olor.

Tadorna cornuta.

Larus argentatus.

Larus tridactylus.

Larus ridibundus.

Larus fuscus.

Larus marinus.

Some of these species are very rare or very local in Ireland, such as Passer montanus, Garrulus glandarius, and Columba xoncs.

The distribution of the other 26 residents may be tabulated as follows. If the total number of residents be added together, it will be found that Scotland heads the list with 98, England follows with 95, whilst Ireland has only 89. It must, however, be remembered that these figures ars exclusive of many species of Winter Visitors, a small minority of which are left behind in autumn, aud are presumably residents, though the great majority of the individuals representing the species in our Islands migrate in spring to more northerly brecoing-grounds, and thus cause the species to be included in the list of Winter Visitors. It is also exclusive of a few specics of summer visitors, of which some individuals remain with us all the winter. 
Partial Residents.

\begin{tabular}{|c|c|c|c|}
\hline & ENGLAND. & Scotland. & IRELAND. \\
\hline 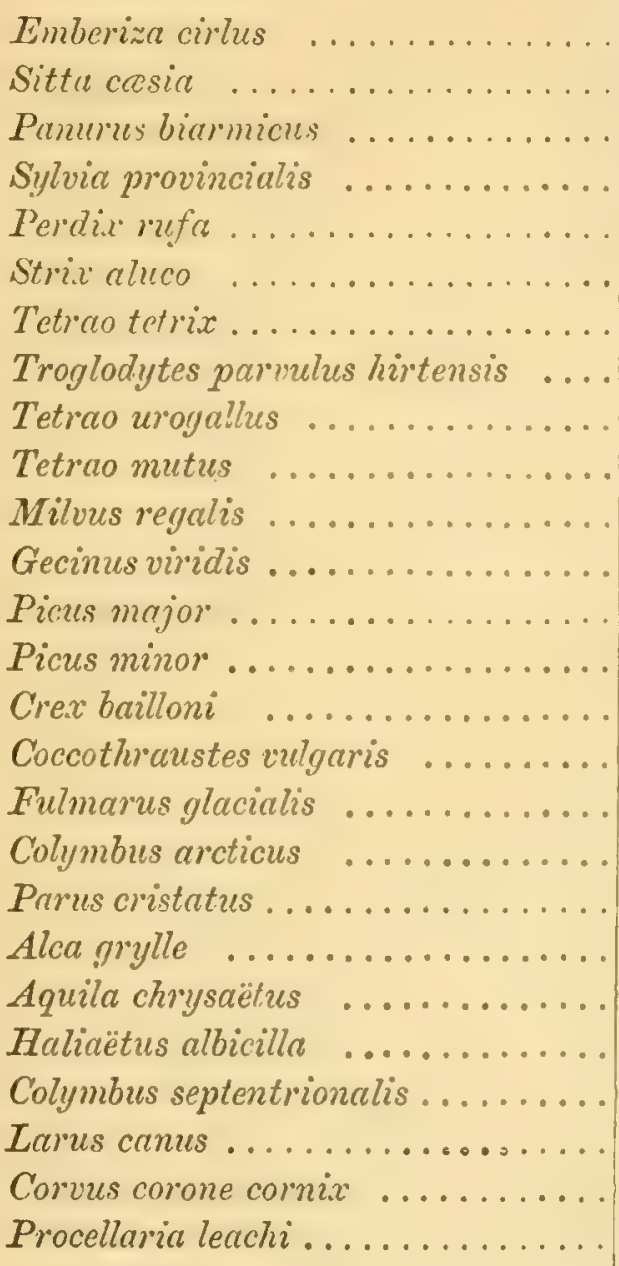 & $\begin{array}{l}\text { Resident. } \\
\text { Accidental. } \\
\text { Winter. }\end{array}$ & $\left\{\begin{array}{l}\text { Accidental. } \\
\text { Absent. } \\
\text { Resident. } \\
\text { Accidental. }\end{array}\right.$ & 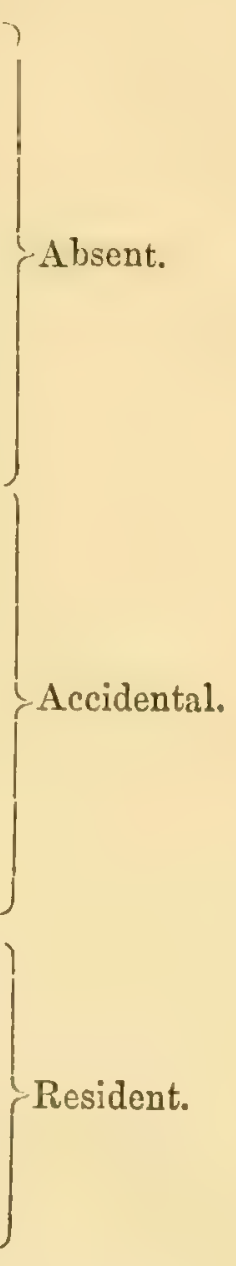 \\
\hline
\end{tabular}

\section{Sumaler Visitors.}

As might be expected, there are no summer visitors to the British Islands that do not visit England. They all come from the south in spring, and could scarcely reach Scotland or Ireland without passing the English coast. There are 4 summer visitors which do not reach Scotland. None of these 4 reach Ireland, and an additional species which objects to cross the sea twice raises the number of summer visitor's which are unknown in Ireland to 5.

There are 48 British Birds which may be regarded as Summer Visitors, though in a few species some stragglers remain behind at the autumn migration and spend the winter with us.

Twenty-seven of these species are more or less common summer visitors to our Islands, and five others may also be regarded as summer 
visitors to the three kingdoms, though they are rare or very local in Ireland :-

Muscicapa grisola.

Acrocephalus phragmitis.

Phylloscopus trochilus.

Phylloscopus rufus.

Locustella locustella.

Sylvia hortensis.

Sylvia cinerea.

Merula torquata.

Saxicola venanthe.

Hirundo rustica.

Chelidon urbica.

Cotyle riparia.

Cuculus canorus.

Cypselus apus.

Caprimulgus europeus.

Crex pratensis.

Crex porzana.

Coturnix communis.

Totanus hypoleucus.

Sterna cantiaca.

Sterna himundo.

Sterna arctica.

Sterna dougalli.

Sterna minuta.

Botaurus minutus.

Ardea nycticorax.

Fratercula arctica.

Pratincola rubetra.

Motacilla raï.

Ruticilla phænicurus.

Sylvia atricapilla.

Phylloscopus sibilatrix.

The last five are very rare and local in Ireland.

The distribution of the partial summer visitors may be tabulated as follows. If the total number of summer visitors be added together, it will be found that England heads the list with 48, Scotland follows with 36, whilst Ireland has only 33 . 


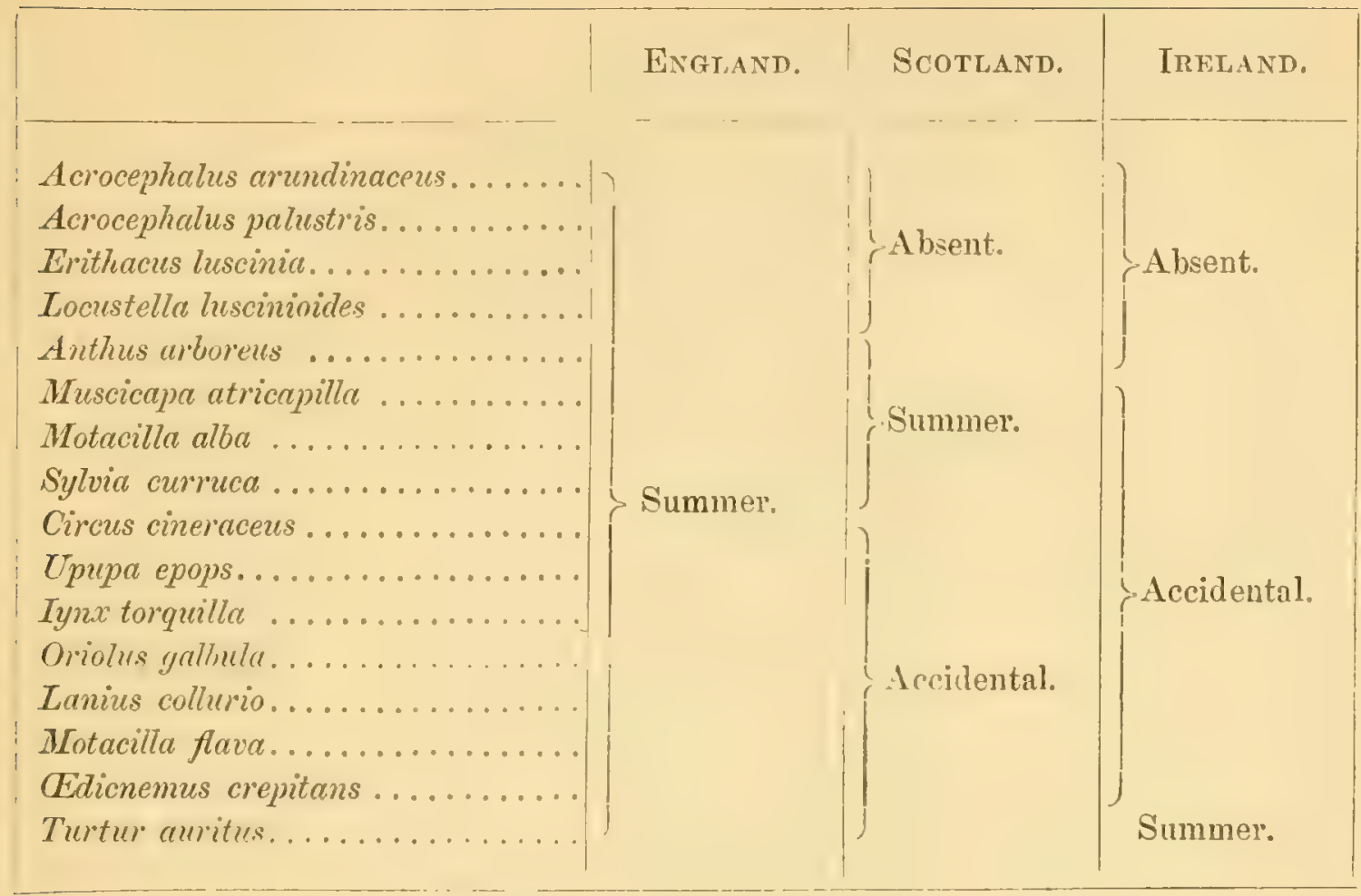

\section{Vinter Visitors.}

The Winter Visitor's to the British Islands appear to deal very impartially with the three kingdoms. They all visit England, all but one Scotland, and all but two Irelaud. The total number of species which may be regarded as winter visitors to England is 68 , Scotland follows with 67 , and Ireland with 66.

There are 68 British Birds which may be regarded as winter visitor's, though in a few species a greater or less number of individuals remain to breed, for the most part in Scotland.

Forty-three of these species are more or less common Winter Visitor's to the three kingdoms, but never breed in any of them :-

Archibuteo lagopus.

Accipiter palumbarius.

Surnia nyctea.

Parus ater.

Loxia leucoptera bifasciata.

Loxia curvirostra pityopsittacus.

Fringilla linaria.

Fringilla montifringilla.

Ampelis garrulus.

Ruticilla tithys.

Lanius excubitor.

Turdus pilaris. 
Turdus iliacus.

Grus communis.

Otis tetrax.

Scolopax gallinula.

Phalaropus fulicarius.

Tringa maritima.

Tringa canutus.

Stercorarius buffoni.

Stercorarius pomarimus.

Larus glaucus.

Lamus sabini.

Larus eburneus.

Larus minutus.

Podiceps rubricollis.

Cygnus musicus.

Cygnus bewicki.

Anser brachyrhynchus.

Anser albifrons.

Anser segetum.

Bernicla leucopsis.

Bernicla brenta.

Mergus albellus.

Somateria spectabilis.

Fuligula nigra.

Fuligula fusca.

Fuligula clangula.

Fuligula glucialis.

Fuligula marila.

Alca alle.

Colymbus glacialis.

Puffinus griseus.

'Twenty-two of these species are more or less common winter visitors to the three kingdoms, and are represented in summer by few or many residents, as the case may be, that remain to breed, twelve of them in England, Scotland, and Ireland :-

Circus cyaneus,

Strix brachyotus,

Fringilla spinus,

Anas boschas,

Anas clypeata, 
Anas crecca,

Anas strepera,

Fuligula cristata,

Fuligula ferina,

Tringa alpina,

Scolopax rusticolu,

Chavadrius pluvialis ;

one in England and Scotland only-

Somateria mollissima ;

three in Scotland and Ireland only-

Meryus serrator,

Anas acuta,

Anas penelope;

and six in Scotland only-
Emberiza nivalis,
Podiceps cornutus,
Stercorarius richardsoni,
Stercorarius catarrhactes,
Anser cinereus,
Mergus merganser.

The remaining three are more or less common winter visitors to Engrland, but are not known to visit Ireland, and the last mentioned is nnknown in Scotland as well :-

Alauda alpestris.

Otis tarda (formerly breeding).

Regulus ignicapillus.

\section{Spring and Autumn Migrants.}

All the Spring and Autumn Migrants visit England. Three appear to alsent themsclves from Scotland, and the same number from Ireland. The number of English spring and autumn migrants may be estimated at 32, whilst that of Scotch and Irish is only 29.

There are 32 British Birds which may be regarded as Spring and Autumn Migrants, though in some cases a few individuals remain in antumn to winter with us and a few remain in spring to breed in some part of our Islands. 
Of these species 18 are spring and autumn migrants to the three kingdoms, but do not breed in any of them :-

Coracias garrula.

Crex parva.

Scolopar major.

Charadrius hiaticula.

Charadrius helveticus.

Limosa melanura.

Limosa rufa.

Totanus fuscus.

Totanus ochropus.

Totanus glareola.

Strepsilas interpres.

Tringa subarquata.

Tringa temmincki.

Tringa arenaria.

Tringa minuta.

Himantopus avocetta.

Sterna nigra.

Podiceps nigricollis.

Four otlier species pass aloug our shores in spring and autumn without leaving any behind in spring to breed; but the first and second have only been recoried from England, the third only from England and Scotland, and the fourth only from England and Ireland:-

Sterna caspia.

Sterna anglica.

Erithacus suecica.

Tringa platyrhyncha.

Ten specics which are principally known as spring and autumn migrants are represented in summer by a few iudividuals that remain to breed, the first and sceond in all three kingdoms, the third in England and Scotland, the fourth, fifth, sixth, and seventh in Scotland only, and the eighth, uintl, and tenth in England only:-

Charadrius morinellus.

Anas circia.

Pernis apivorus.

Pandion haliaëtus.

Phalaropus hyperboreus.

Totanus glottis.

Numenius phropus. 
Charadrius cantianus.

Totanus pugnax.

Falco subbuteo.

\section{Accidental Visitors.}

There are several reasons why the number of Accidental Visitors to England should so largely exceed those known to have occurred in Scotland or Ireland. England contains a much larger area than either of the sister kingdoms. The number of people capable of recognizing a strange visitor is very much larger. Very many of our Accidental Visitors breed in South Europe and visit us in spring, having overshot the mark on their spring migration. Probably very few of them which reach our shores pass on to Scotland or Ireland.

The total number of Accidental Visitor's may be estimated at 135 ; of which 126 have been recorded from England, 58 from Scotland, and 58 from Ireland.

Of the species of British Birds whose appearance in our Islands is so irregular or so seldom that they can only be regarded as Accidental Visitors, thirty-five have been recorded from all three kingdoms :-

Falco vespertinus.

Falco gyrfálco islandus.

Falco gyrfalco canaicans.

Circus reruginosus.

Scops scops.

Merops apiaster.

Pastor roseus.

Lanius major:.

Geocichla varia.

Phylloscopus superciliosus.

Sylvia nisoria.

Emberiza lapponica.

Emberia hortulanu.

Ectopistes migratorius.

Syrrhaptes paradoxus.

Botaurus lentiginosus.

Platalea leucorodia.

Ardea purpurea.

Ardea comata.

Ciconia alba.

Tringa pectoralis.

Tringa rufescens. 
Numenius borealis.

Himantopus candidus.

Glareola pratincola.

Larus philadelphia.

Larus leucopterus.

Bernicla ruficollis.

Tadorna metila.

Fuligula perspicillata.

Fuligula albeola.

Fuligula rufina.

Fuligula nyroca.

Puffinus major.

Oceanites wilsoni.

"lwenty have been recorded from England and Scotland, but not from Ireland:-

Bubo maximus.

Strix tengmalmi.

Surnia funerea.

Surnia funerea hudsonia.

Nucifraga caryocatactes.

Merula atrigularis.

Saxicola deserti.

Anthus cervinus.

Anthus richardi.

Emberiza melanocephala.

Ardea alba.

Ardea garzetta.

Totanus macularius.

Totanus solitavius.

Macrorhamphus griseus.

Charadrius fulvus.

Charadrius fulvus americamus.

Cursorius gallicus.

Fuligula histrionica.

Alca troile brunnichi.

Fiftcon have becn recorded from England and Ireland, but not firom Scotland :-

Aquila navia.

Falco cenchris.

Cinclus aquaticus melanogaster.

Muscicapa parva. 
Hypolais hypolais.

Alauda brachydactyla.

Cuculus glandarius.

Coccyzus americanus.

Cypselus melba.

Ibis falcinellus.

Tringa bonapartii.

Sterna hybrida.

Sterna leucoptera.

Puffinus obscurus.

Mergus cucullatus.

T'wo species have been recorded from Scotland and Ireland, but not from England :-

Accipiter atricapillus.

Alca impennis (recently extinct).

One species has been recorded from Scotland only :-

Grus virgo.

Six species have been recorded from Ireland only :-

Turdus migratorius.

Gyps fulvus.

Coccyzus erythrophthalmus.

Anser stolidus.

Anser hyperboreus.

Daption capense.

No fewer than fifty-six species have been recorded from England only :-

Neophron percnopterus.

Milvus ater.

Falco gyrfalco.

Fringilla linaria hornemanni.

Alauda cristata.

Alauda sibirica.

Anthus spinoletta.

Anthus campestris.

Caprimulgus agyptius.

Caprimulgus ruficollis.

Chatura caudacuta.

Turtur orientalis.

Crex carolina.

Otis macqueeni. 
Ardea bubulcus.

Ardea virescens.

Ciconia nigra.

Charadrius vociferus.

Charadrius minor.

Charadrius asiaticus.

Vanellus gregarius.

Totanus bartrami.

Totanus flavipes.

Tringa minutilla.

Tringa acuminata.

Noctua noctua.

Lanius rufus.

Lanius minor.

Geocichla sibirica.

Monticola saxatilis.

Saxicola stapazina.

Saxicola isbellina.

Acrocephalus aquaticus.

Acrocephalus turdoides.

Sylvia galactodes.

Sylvia orpheus.

Acredula caudata.

Tichodroma muraria.

Accentor alpinus.

Emberiza pusilla.

Emberiza rustica.

Carpodacus enucleator.

Carpodacus erythrinus.

Loxia leucoptera.

Larus rossi.

Larus ichthyaëtus.

Larus melanocephalus.

Sterna fuliginosa.

Sterna anrestheta.

Colymbus adamsi.

Estreluta hesitata.

Ostrelata torquata.

Bulweria columbina.

Somateria stelleri.

Anser minutus.

Anas carolinensis. 


\section{Geographical Distribution of British Birds during the Breeding-season outside the British Islands.}

The breeding-range of the 391 species and subspecies of Birds which undoubtedly have a claim to he regarded as British varies very greatly both in the degrees of longitude which each species covers during the breedingseason, and the climates which they seleet for their breeding-grounds.

The British Islands, being situated in the Palaearctic Region, which cxtends castwards across Lurope and Siberia to Japan, are naturally frequented by more species belonging to that Region than by those belonging to any other Zoological Region. A bout 28 per cent. breed across the Palæarctic Region from the Atlantic to the Pacific, but are not known to breed in the Nearctic Region. A bout 15 per cent. more breed across both these Regions. 'The breeding-range of another 15 per cent. may be described as Wrest Palicarctic, cxtending from the British Islands to Central Asia, whilst that of an additional 11 per cent. extends some way into Asia, but not as far as the Yenesei. The breeding-range of about (i per cent. may be described as European and that of about 3 per cent. as West European. About 5 per cent. may be regarded as North Atlantic species, breeding on the coasts of West Europe and East North America and on many of the intervening Atlantic Islands. About 4 per cent. may be described as Circumtropical, breeding on tropical islands. About 8 per cent. are wanderers from the Nearetic Region which are not known to breed in any part of the Palaearetic Region, whilst 2 per cent. are wanderers from East $\Lambda$ sia, 2 per cent. from Central Asia, and 1 per cent. from East Europe.

British Birds may be classified according to their brecding-ranges as follows :-

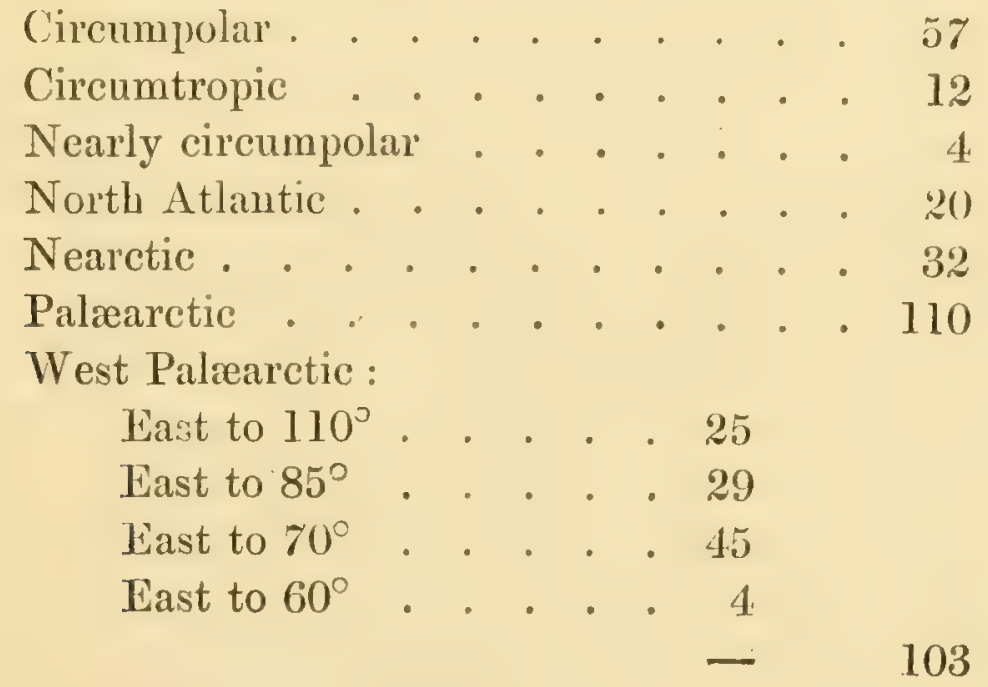

Carried forward 


\begin{tabular}{|c|c|c|c|c|}
\hline Brought forward . & . . & & , & \\
\hline East to $50^{\circ}$ & . . & . & 19 & \\
\hline East to $25^{\circ}$ & . & . & 2 & \\
\hline Not east of $10^{\circ}$ & . & . & 10 & \\
\hline & & & - & \\
\hline East Palrearctic. & . & . & . & \\
\hline Central Palæarctic. & . . & . & . . & . \\
\hline
\end{tabular}

\section{Circumpolar and Circuntropic Species.}

There are no fewer than 69 species of British Birds whose breedingrange may be regarded as circumpolar or circumtropical. They may be classificd according to the climatic range of their breeding-grounds as follows :-

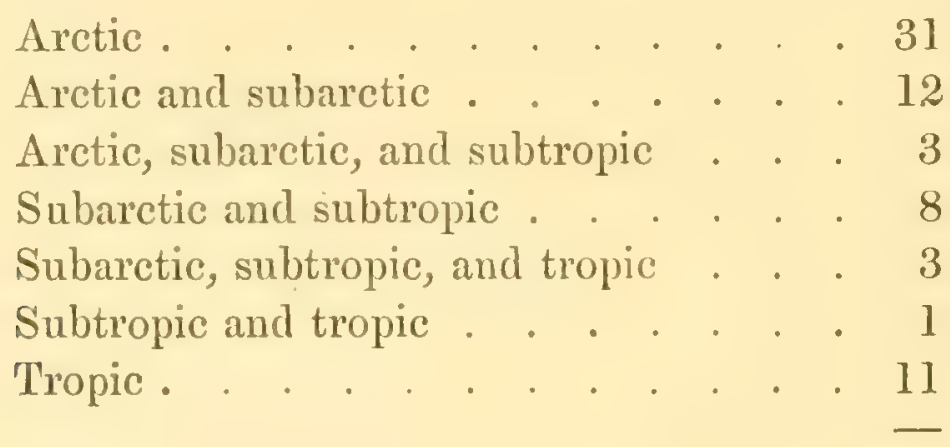

Of the thirty-one aretic species, the first two breed in some number's within the limits of our Islands, the next three in much smaller numbers, and the next two occasionally :-

Tetrao mutus.

Fulmarus glacialis.

Colymbus arcticus.

Colymbus septentrionalis.

Phalaropus hyperboreus.

Emberiza nivalis.

Fuligula marila. Anser albifrons.

Anas acuta.

Tringa canutus.

Tringa maritima.

Tringa arenaria.

Fuligula glacialis.

Charadrius helveticus. 
Stercorarius buffoni.

Stercorarius pomarinus.

Phalaropus fulicarius.

Ampelis garrulus.

Fringilla linaria.

Alauda alpestris.

Somateria spectabilis.

Lurus glaucus.

Larus rossi.

Larus sabini.

Surnea nyctea.

Larus eburneus.

Emberiza lapponica.

Strix tengmalmi.

Carpodacus enucleator.

Colymbus adamsi.

Anser hyperboreus.

Of the twelve species whose breeding-range is both aretic and subaretic all exeept the last two on the list breed within the limits of the British Islands :-

Falco peregrinus.

Alca troile.

Larus marinus.

Larus tridactylus.

Mergus serrator.

Stercorarius richarlsoni.

Tringa alpina.

Strix brachyotus.

Anas clypeata.

Sterna arctica.

Fuligula clangula.

Strepsilas interpres.

The brecding-range of the three following species is not only arctic, but also subarctic and subtropic: they all breed within the limits of the British Islands :-

Corvus corax.

Aquila chrysaëtus.

Cotyle riparia.

The breeding-range of the eight following species extends to both the subarctic and subtropic divisions of the Temperate Region. The two first named breed in some numbers within the limits of the British Islands, the 
threc next more locally, and it is supposed that the sixth occasionally does so :-

\author{
Certhia familiaris. \\ Anas boschas. \\ Anas strepera. \\ Pandion haliaëtus. \\ Procellaria leachi. \\ Podiceps cornutus. \\ Podiceps rubricollis. \\ Anthus spinoletta.
}

The breeding-range of the three following species is not only subarctic and subtropic, but is also tropic. The first-mentioned breeds commonly within the limits of the British Islands, the next used locally to do so in small numbers, but the last has not been found breeding on our coasts:-

\title{
Aluco flammens. \\ Sterna dougalli. \\ Sterna caspia.
}

The breeding-range of one species may be regarded as subtropic and tropic-

\section{Ardea nycticorax.}

Eleven species may be regarded as circumtropic. They are oceanic birds which breed on islands within the tropies, and are of course only accidental visitors of more or less frequent occurrence to our Islands :-

\section{Estrelata hesitata.}

QEstrelata torquata.

Bulweria columbina.

Puffinus mujor.

Puffinus griseus.

Puffinus obscurus.

Daption capense.

Oceanites wilsoni.

Anous stolidus.

Sterna fuliginosa.

Sterna ancestheta.

\section{Nearly Circumpolar Species.}

Four species of birds which are included in the British List are mol'c than Palaearetic in their brecding-range, but are not quite circumpolar. 'The three first named breed regularly in the British Islands, and the last is said to have done so:- 


\section{Phalacrocorax carbo.}

The breeding-range of this species extends across $\Lambda$ sia and Europe to Iceland, Greenland, and the coasts of Labrador.

\section{Saxicola ænanthe.}

The breeding-range of the Wheatear extends across Asia to Alaska on the one hand, and across Europe to Iceland, Greenland, and the coasts of Labrador on the other.

\section{Pica caudata.}

The breeding-range of the Magpie extends across Europe and Asia to Alaska and the Western States.

\section{Podiceps nigricollis.}

The breeding-range of the Eared Grebe extends arross Europe and Asia to the Western States, and probably occurs in Alaska. To the south it extends far into the Tropies both in Africa and America.

Of these four species the Cormorant may be regarded as subarctic, subtropic, and tropic in its breeding-range, the Wheatear and the Magpie as arctic, subarctic, and subtropic, and the Grebe as subarctic, subtropic, and tropic.

\section{North Atrantic Species.}

There are 20 species of British Birds which may be regarded as North Atlantic species, inasmuch as they breed for the most part on islands in the North Atlantic Ocean, and occasionally on cliff's on both its American and European shores, but are unknown in the Pacific Ocean. Six of these only breed in an arctic climate:-

Alca alle.

Alca troile brunnichi.

Colymbus glacialis.

Anser brachyrhynchus.

Bernicla leucopsis.

Bernicla brenta.

Five others breed not only in an arctic climate, but also in a subarctic :-

Larus argentatus.

Alca torda.

Alca grylle.

Fratercula arctica.

Somateria mollissima. 
Four species are only known to breed in a subarctic climate :-

Alca impennis (extinct).

Stercorarius catarhactes.

Procellaria pelagica.

Sula bassana.

The breedinn-range of three species extends both to subaretic and subtropical climates :-

Sterna hivundo.

Sterna nigra.

Puffinus anglorum.

The brecding-range of two other species is also subaretic and subtropical, but it extends beyond into the tropics :-

Sterna anglica.

Sterna cantiaca.

Nearctic Species.

There are no fewer than 32 species of birds which are regarded as ancidental visitors to our Islands whose hreeding-range is confined to the American continent and the islands near it. Of these, fifteen are exclusively aretic in their breeding-range:-

Fringilla linaria hornemanni,

Falco gyrfalco candicans,

Falco gyrfalco islandus,

Surnia funerea hudsonia,

Charadrius fulvus americanus,

Numenius borealis,

Tringa bonapartii,

Tringa rufescens,

Tringa pectoralis,

Tringa minutilla,

Totanus flavipes,

Macrorhamphus griseus,

Larus leucopterus,

Fuligula albeola,

Fuligula histrionica;

five are both arctic and subarctic in their breeding-range :-

Loxia leucoptera, Accipiter atricapillus,

Mergus cucullatus,

Anas carolinensis,

Fuligula perspicillata; 
one is arctic, subarctic, and subtropic:-

Turdus migratorius;

three are subarctic only :-

Larus philadelphia, Totanus solitarius, Crex carolina;

six breed both in subarctic and subtropical climates :-

Coccyzus americanus,

Coccyzus erythrophthalmus,

Ectopistes migratorius,

Totanus bartrami,

Totanus macularius,

Charadrius vociferus;

whilst the breeding-range of two extends not only to subaretic and subtropic climates, but also to the tropics:-

Botaurus lentiginosus, Ardea virescens.

\section{Palmarctic Species.}

The breeding-ranges of 110 species of British Birds may be regarded as Paliearetic. They extend across Europe and Asia from the Atlantic to the Pacific, but are not known to reach any part of the American continent, nor as a rule to extend beyond the aretic or temperate climates to the tropics. There are, however, a few birds whose climatic tastes are so cosmopolitan that their breeding-ranges not only reach both the subaretic and subtropic climates of the Temperate Region, but cover the tropies as well. These birds may be classified according to the climatic rauge of their breeding-grounds as follows :--

Aretic . . . . . . . . . 17

Arctic and subarctic . . . . . . . 15

Subarctic . . . . . . . . . 15

Subarctic and subtropic . . . . . 49

Subarctic, subtropic, and tropic . . 8

Subtropic . . . . . . . . . . 1

Subtropic and tropic . . . . . . 5 
Of the seventeen species which breed only in an arctic climate a few individuals of the two first mentioned find what they require on some of the Scoteh Islands. It may be remarked that they belong principally to the Limicolie, though the list contains a few Anseres, three Passcrine Bircis, and an $\mathrm{Owl}$ :-

Numenius pheopus.

Totanus glottis.

Tringa temmincki.

Tringa subarquata.

Tringa platyrliyncha.

Totanus fuscus.

Limosa mifa.

Scolopax gallinula.

Cygnus musicus.

Cygnus bewicki.

Anser segetum.

Anser minutus.

Somateria stelleri.

Erithacus suecica.

Anthus cervinus.

Emberiza pusilla.

Surnia funerea.

Of the fifteen species whose breeding-range is both aretic and subaretic at least half of them breed in greater or less numbers in our Islands:--

Falco resalon.

Larus canus.

Charadrius morinellus.

Circus cyaneus.

Anas crecca.

Mergus merganser.

Anas penelope.

Totanus glareola.

Totanus pugnax.

Mergus albellus.

Grus communis.

Loxia leucoptera bifasciata.

Bubo maximus.

Emberiza rustica .

Nucifraga caryocatactes. 
Of the fifteen species whose breeding-range is subarctic only, more than half breed in our Islands :-

Loxia curvirostra.

Fuligula cristata.

Fuligula rufina.

Scolopax rusticola.

Scolopax gallinago.

Fringilla spinus.

Tetreo tetrix.

Anas circia.

Numenius arquata.

Regulus cristatus.

Larus ridibundus.

Totanus ochropus.

Fringilla montifringilla.

Larus minutus.

Acredula coudata.

Of the forty-nine species which are both subarctic and subtropic in their breeding-range, no fewer than thirty-seren breed in our Islands, and of these twenty-nine may be regarded as residents. Nearly half of this group of species belong to the Passeres:-

Sitta cresia.

Cinclus aquaticus.

Garrulus glandarius.

Passer montanus.

Passer domesticus.

Coccothraustes vulyaris.

Corvus corone.

Picus minor.

Haliaëtus albicilla.

Accipiter nisus.

Motacilla boarula.

Pyrrhula vulgaris.

Troglodytes parvulus.

Parus major.

Columba livia.

Strix aluco.

Picus major.

Botaurus stellaris.

Falco timunculus.

Vamellus cristutus. 
Podiceps cristatus.

Coturnix communis.

Totanus calidris.

Strix olus.

Ėmberiza schenichs.

Pyrrllocorax graculus.

Alauda arvensis.

Tadorna cornuta.

Motacilla flava.

Sylvia curruca.

Cuculus canorus.

Charadrius cantianus.

Cypselus apus.

Hirundo mstica.

Iynx torquilla.

Falco subbuteo.

Totanus hypoleucus.

Limosa melanura.

Pernis apivorus.

Pames ater.

Pavus palustris.

Accipiter palumbarius.

Circus cruginosus.

Ciconia nigra.

Tichodroma muraria.

Cinaradrins minor.

Tadorna rutila.

Sterna lencoptera.

Anser cinerous.

One specics apnears to be restricted to a sulptropic climate during the breeding season:-

Monticola saxatilis.

The species whose breeding-range extends not only over both the northern and the sonthen divisions of the Temperate Region, but also to the Tropics, are as follows:-

Ardea cinerea.

Podiceps minor.

Fulica atra.

Gallimula chloropus.

Alcerlo ispirla. 


\title{
Himantopus avocetta. \\ Upupa epops. \\ Platalea lencoroctia.
}

The range of the following fire species does not extend quite so far north, being only tropic and subtropic:-

\author{
Himantopus candidus. \\ Ardea purpurea. \\ Arlea garzetia. \\ Ardea alba. \\ Sternce hybrida.
}

\section{West Palatearctic Species.}

There are no fewer than $13:$ species of British Birds whose breedingrange is confined to the western hali of the Paliearctic Region. Of these, 10 do not extend castwards beyond longitude $10^{\circ}$, 2 reach $25^{\circ}$, 19 are found as far as $50^{\circ}$, and $\frac{1}{2}$ as far as $60^{\circ}$, 15 breed as far east as $70^{\circ}$, the range of 29 extends to $85^{\circ}$, and that of 25 to $110^{\circ}$, beyoud which the East Palæarctic Region is entered.

\section{Species whose Breeding-range extends from the Atlantic to Longitude $110^{\circ}$.}

There are twenty-fire species of British Birds whose breeding-range extends from the British Islands eastwards across Europe and West Siberia, but does not extend (so far as is known) into Last Siberia. The West Palraretic Recion extends to the basin of the Yenesei about longitude $110^{\circ}$. Nature has fixed this boundary very exactly. The Himalayas form a barricr which many migratory birds object to cross. The autumnal stream of birds seeking milder winter-quarters divides, half the species migrating westwards to winter in the basins of the Caspian and Mediterranean seas if they do not wander as far as Africa, and the other half migrating enstrards to winter in Japan, China, and the islands of the Malay Archipelago if they do not wander as far as Australia. Birds breeding in the valley of the Yenesei migrate westwards in autumn, whilst those breeding in the valley of the Lena migrate eastwards. Of the twenty-five species whose breeding-range extends to longitude $110^{\circ}$, that of three may be regarded as arctic:-

\section{Fuligula nigra. Archibuteo lagopus. Tringa minuta.}


T'he following ten species are subarctic as well as aretic:-

Tetrao urogallus.

Phylloscopus trochilus.

Motacilla alba.

Fuligula fusca.

Turdus pilaris.

Charadrius pluvialis.

Acrocephahus phragmitis.

Ruticilla phonicurus.

Charadrius hiaticula.

Scolopax major.

The breeding-range of the following five species may be regarded as subarctic :-

\section{Anthus arboreus.}

Circus cineraceus.

Sturnus vulgaris.

Turdus viscinorus.

Turdus musicus.

The following six species brecd in subaretic and subtropic climates :-

Muscicapa grisola.

Falco vespertinus.

Fringilla carduelis.

Corvus monedula.

Cygnus olor.

Oriolus galbula.

One species appears to breed in subtropic climates only:-

Girus virgo.

Species whose Breeding-range extends from the Atlantic to Longitude $85^{\circ}$.

The breeding-range of twenty-nine species of British Birds extends from the Atlantic as far east as abont longitude $85^{\circ}$, reaching across Europe and West Siberia, inchuding the valley of the $\mathrm{Ob}$; and further sonth embracing Chinese Turkestan and Kashmir.

None of these species breed in the Aretic Regions, but three of them may be regarded as subarctic :-

Muscicapa parva.

Hypolais hypolais.

Syluia misoria. 
Most of them (as many as nineteen) breed both in subarctic and in subtropic climates :-

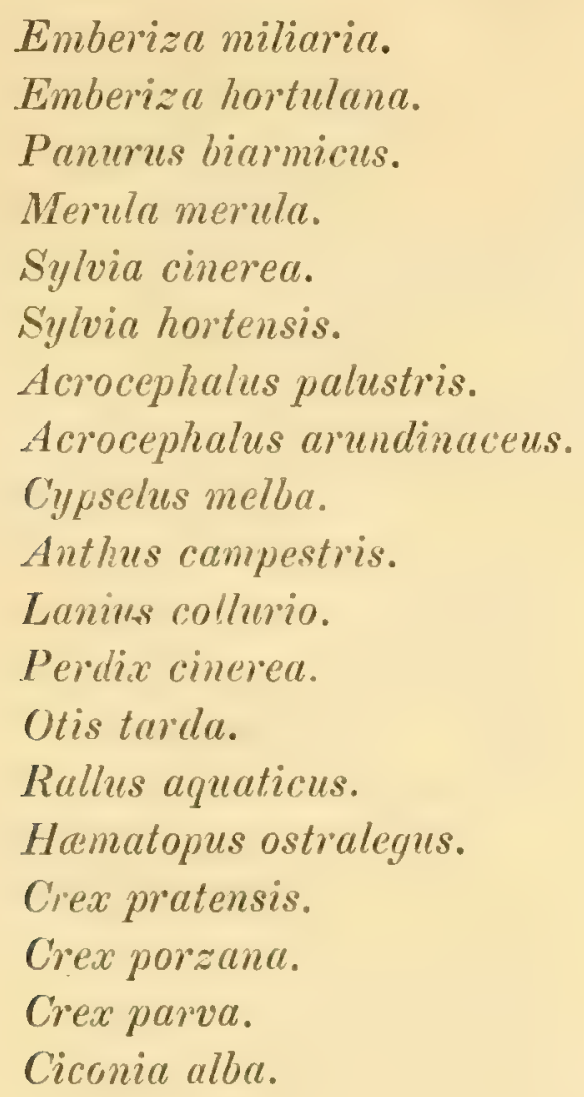

The breeding-range of two species extends not only to subarctic and subtropic climates but also to the tropics:-

Edicnemus crepitans.

Coracias garrula.

Four species may be regarded as exclusively subtropic in their breedingrange :-

\section{Lanius minor.}

Merops apiuster.

Otis tetrax.

Fuligula nyroca.

The breeding-range of one species is both subtropic and tropic:-

Ibis falcinellus. 
Species whose Breeding-range extends from the Atlantic to Longitude $70^{\circ}$.

The breching-range of forty-five species of British Birds extends from the Atlintic as far east as abont longitude $70^{\circ}$, an area which inchudes Furope, the valley of the Tlobol, the basin of the Aral Sea, Asia Minor, Persia, Afghanistan, and Baluchistan.

Of these species none are cxciusively arcic in their breeding-range, but fire breed both in arctic and subarctic climates, and the range of the last mentioned also extends to subtropic climates :-

Emberiza citrinella.

Anthus pratensis.

Turdus iliacus.

Merula torquata.

Chetidon urbica.

Nine species may be resuried as cuchsively subaretic in their brecdingrauges :-

Columba palumbus.

Fringilla chloris.

Fringilla calebs.

Muscicapa atricapilla.

Accentor alpinus.

Corvus frugilegus.

Alauda arborea.

Motacilla raii.

Pratincola rubetra.

The brecding-lange of serentecus species is not only subaretic but also subtropic :-

Buteo vulgaris.

Milvus ater.

Scops scops.

Gecimus viridis.

Caprimulgus europaus.

Erithacus rubecula.

Fringilla camabina.

Sylvia atricapilla.

Ruticilla tithys.

Locustella luscinioides.

Acrocephalus turdoides.

Alauda cristata. 
Lanius rufus.

Turtur auritus.

Columba oenas.

Botaurus minutus.

Sterna minuta.

The breeding-range of tinteen species may be regarded as exclusively subtropic:-

Saxicola deserti.

Saxicola stapazina.

Sylvia orpheus.

Sylvia galactodes.

Alauda brachydactyla.

Emberiza melanocephala.

Cuculus glandarius.

Falco cenchris.

Neophron percnopterus.

Gyps fulvus.

Cursorins gallicus.

Glarenla pratincola.

Fuligula rufina.

The breeding-range of one species is subtropic and tropic:Ardea comata.

Species whose Breeding-range extends from the Atlantic to Longitude $60^{\circ}$.

The brecling-range of four species of British Birds extends from the Atlantic as far cast as the Ural Monntains, about longitude $60^{\circ}$. They all breed in a subarctic climate, but the range of the last mentioned is also subtropic:-

Accentor modularis.

Lanius excubitor.

Parus cristatus.

Parus caruleus. 
Species whose Breeding-range extends from the Atlantic to Longitude $50^{\circ}$.

The breeding-range of nineteen species of British Birds extends from the Atlantic to about longitude $50^{\circ}$, an area which enbraces the valleys of the Drina and the Volga, the Cancasus, Asia Minor, and Palestine.

None of them are exclusirely arctic in their breeding-range, but three species breed in arctic and subarctic climates:-

Anthus obscurus.

Lames fuscus.

Cinclus aquaticus melanogaster.

Seren species may be regarded as exclusively subatretic in their breedingrange :-
Pratincola rubicola.
Emberia cirlus.
Plyylloscopus sibilatrix.
Locustella locustella.
Acrocephalus aquaticus.
Milvus regalis.
Aquila novia.

Six species are not ouly subarctic, but also subtropic in their breedingrange :-

Regulus ignicapillus.

Erithacus Iuscinia.

Phylloscopus rufus.

Sylvia provincialis.

Noctua noctua.

Phalacrocorax graculus.

The breeding-range of one specius extends not only to subaretic and subtropic climates but is also tropic-

\section{Crex bailloni ;}

whilst that of a second species may be regarded as exclusively subtropicLarus melanocephalus, and that of a third species as subtropic and tropicArdea bubulcus. 
Species whose Breeding-range is confined to Western Europe.

'There are six specics and as many subspecies of British Birds whose breeding-range is confined to Western Europe.

One species is arctic and subarctic and may breed as far east as longitude $25^{\circ}:-$

\section{Fringilla flavirostris.}

Four species are not known to breed further cast than longitude $10^{\circ}$. 'Two of them are subaretic-

Acredula rosea, Motacilla yarrelli;

one is subarctic and subtropic-

$$
\text { Perdix rufa ; }
$$

and the fourth is subtropic-

\section{Caprimulgus ruficollis.}

'The breeding-range of three subspecies is about the same, of which one is arctic-

$$
\text { Falco gyvfalco (typicus), }
$$

and three are subarctic-

Charadrius hiaticula major,

Loxia curvirostra pilyopsittaca,

Fringilla linaria rufescens.

Only one species is exclusively British-

Tetrao scoticus ;

but the Wren of St. Kilda and the British Coal Tit claim subspecific rank-

Troglodytes parvulus hirtensis.

Parus ater britannicus.

\section{East Palahetic Species.}

There are nine accidental risitors to our Islands which may be regarded as liast Palrearotic, inasmuch as their breeling-ranges extend as far east as the Pacific, but not as fal west as the Atlautic. Of these there are six 
whose breeding-range is supposed to be confined to the Eastern Palrarctic Region, from the valley of the Fenesci to the Pacific. Of these two are supposed to be exclusively arctic-

\section{Tringa acuminata, Charadrius fulvus ;}

two are arctic and subarctic-

Phylloscopus superciliosus, Geocichla sibirica;

two are only known to breed in a subarctic climate-

Chotura caudacuta, Geocichla varia;

whilst a third is both subtropic aud tropic in its brecding-range-

\section{Turtur orientalis.}

The breeding-range of one species, an accidental visitor from a subarctic climate, extends from the Pacific to the Ural Mountains-

\section{Lanius major.}

The breeding-range of one species, an accidental visitor from a subarctic climate, extends from the Pacific to the Baltic-

Carpodacus erythrinus.

\section{Central Palatarctic Species.}

The brecding-range of thirtecn aceidental visitors may be broadly described as Central Palaearetic, inasmuch as their breeding-ranges neither extend as far west as the Atlantic nor as far cast as the Pacific. Of these the rauge of eight does not extend west of the Caspian Sea nor as far east as China. One is aretic-

\section{Bernicla ruficollis;}

three breed in a subarctic climate-

Anthus richardi, Merula atrigularis, Syrrhaptes paradoxus; 
three choose a subtropic climate-

\section{Charadrius asiaticus, \\ Larus ichthyaëtus, \\ Otis macqueeni ;}

one may be regarded as subtropic and tropic-

\section{Caprimulgus agyptius.}

The breeding-range of one species extends from the valley of the Eibe to that of the Yenesei and may be regarded as subarctic and subtropic-

Corvus corone cornix.

The breeding-range of four species extends from South-cast Russia to some part of Central Asia-

\section{Saxicola isabellina.}

Alauda sibirica.

Vanellus gregarius.

Pastor roseus.

They are all accidental visitors, breeding in a subtropic climate.

\section{Climatic Distribution of British Birds during the Breeding-season.}

Very few birds have a rexy wile climatic distribution during the breeding-scason. They pay little or no attention to parallels of latitude, but they appear to be rery particular to choose brecding-grounds with a mean temperature during the brecding-season to suit their individual requirements. The isotinermal lines of July may be regarded as forming natural boundaries of the latitudinal range of most of our birds during the breeding-season, if due importance be attached to two factors which play a very important part in modifying it. In our maps the isothermal lines are corrected to sea-level. The corrections must of course be entircly dispegarded in considering the breeding-ranges of birds, which are governed by the actual mean temperature, irrespectire of cause. The climate may be produced by a low elcration at a high latitude, or by a high elevation at a comparatively low latitude. For cxample: the climate of the Dovre Fjeld, 6000 fect above the level of the sea in latitude $62^{\circ}$, is very similar to that of Lapland, 60 feet above the level of the sea in latitude $r 0^{\circ}$, and many purely aretic birds and plants are found in both localities.

The other factor which appears to play an important part in reciding the 
breeding-range of many birds, especially of Passerine Birds, which require a long time to rear their young, is the length of the summer.

The breeding-range of many British Birds extends much further north in Scandinavia than it does in East Russia, and in most enses where the brceding-range extends across Asia the birds breed further north in West Siberia than they do in the extreme east of that country. The cause of this peculiarity in the distribution of these birds can scarcely be ascribed to difference of temperature. The isothermal lines of July, which represents midsummer in the Arctic Regions, rise much further north between the White Sca and the Delta of the Lena than they do in Scandinaria or Kamtschatka. The Atlantic eyclones in the west cause the summers of Seandinavia to be cold and wet, whilst the winter accumulation of ice in the Sea of Okotsk lowers the summer temperature of Kamtschatka and the east coast of Siberia.

The probable cause is the difference in the duration of the summers in the different districts. In any given longitude the summers are shorter as the latitude increases. In the valley of the Yenesei $I$ found that the summer advaneed at the rate of 100 miles in 24 hours, which may represent a degree a day after due allowance has been made for the winding of the river. Assuming that the advance of winter is at the same rate, a difference of 10 degrees of latitude would make a difference of 20 days in the duration of summer-a very important curtailment of the time necessary for the sucessful rearing of a brood where the summer's are so short. The fact that snow disappears in North Seandinaria much earlier than it does in the same latitude east of the Th'hite Sea, whilst it lingers much longer in the extreme east of Siberia than it does in the same latitude in Western Siberia, harmonizes with the variation in the latitude at which many birds range during the breeding-season, so that it is difficult to avoid coming to the conclusion that they are cause and effect.

It must, however, be remembered that the mean temperature is only an approximate index to the climate of a district. The mean temperature in July of the Dovre Fjeld is the same as that of the plains three or four hundred miles further north. The shortness of the summer nights in latitude $62^{\circ}$ causes the climatic condition of the two localities to vary so little that their fauna and flora are almost the same. It is obvious that somewhere in the Alps a similar mean temperature is to b: found in July; but in latitude $47^{\circ}$ the climatic conditions are very different: the temperature during the day is considerably raised by a much more vertical sun, and the much longer duration of night causes the extremes of temperature to vary so much during the twenty-four hour's that a very different climate is the result. Adult birds easily adapt themselves to considerable extremes of temperature provided always that they can obtain a sufficicnt supply of food; but most of them are careful to aroid 
great extremes for their young. Hence, though we find an epitome of Aretic ormithology on the tundras of the Dovre Fjeld, we look in vain for a similar epitome on the higher Alps. Though the mean temperature during July may be the same, the cold nights produce a climate sufficicntly different to prevent most Arctic Birds from using it as a brecking-ground. It cannot be too clearly laid down that the latitudinal distribution of Birds is purely climatic.

The division of the summer climate of the world into three zones-Aretic, Temperate, and Tropic-is scarcely narrow enough for the present purpose, and it will be nore convenicut to restrict somewhat the limits of the Aretic and Tropic zones, and split the Temperate zone in two parts, which might be called Subarctic and Subtropic respectively.

The mean temperature for July would then range as follows in each of the four climates :-

Arctic from $40^{\circ}$ to $53^{\circ}$, including Iceland, the Highlands of Scotlaud, North Scandinaria, the Dovre Fjeld, the tundras of Last Russia and Siberia, and the mountains of East Siberia.

Subarctic from $53^{\circ}$ to $65^{\circ}$, including the British Islands, Central Europe, South Siberia, and the north island of Japan.

Subtropic from $65^{\circ}$ to $77^{\circ}$, including South Europe, the mountains of North Africa, Asia Minor, Central Asia, North China, and the south island of Japan.

Tropic from $77^{\circ}$ to $90^{\circ}$, including the plains of North Africa, Arabia, India, South China, and the Malay Archipelago.

The climatic breeding-range of British Birds may be summarized as follows :-

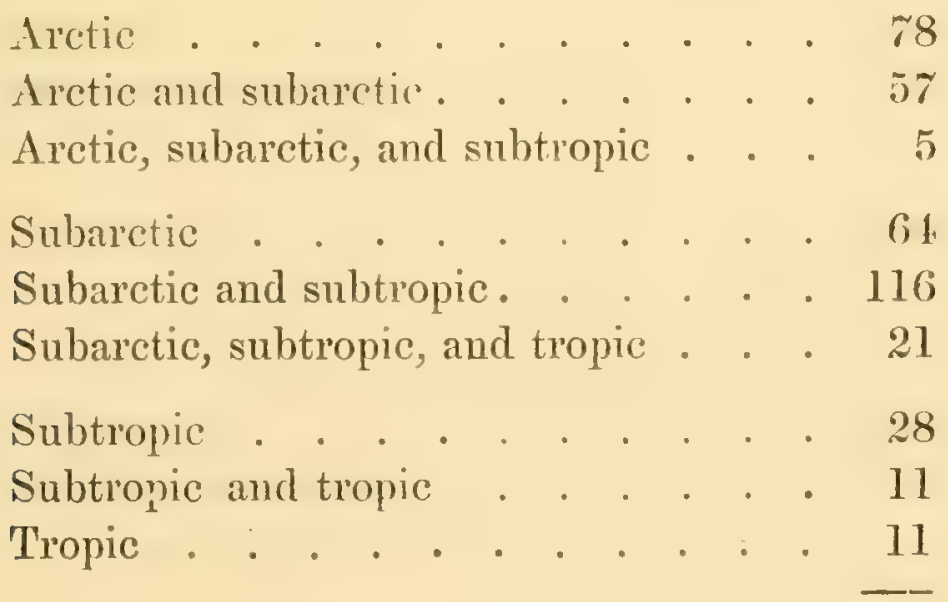





\section{APPENDIX.}

BRIEF SUMMARY

OF TIIE

GEOGRAPIICAL DISTRIBUTION OF EACH BRTTISII BIRD,

IBTII

WITHIN AND WITHOUT THE BRITISH ISLANDS;

ART'viHI Fur

LABELS OF COLLECTIONS OF BRITISH BIRDS OR EGGS. 



\title{
Order PICO-PASSERES.
}

\section{Suborder PASSERES.}

\author{
Family PASSERIDÆ.
}

Subfamily TURDIN

\section{WHITE'S THRUSH. Geocichla varia.}

Accidental winter visitor (a score records, including three Irish and one Scotch). Breeds in South-eastern Siberia, and probably in North China. Winters in Japan, South China, and the adjacent islands.

\section{SIBERIAN THRUSH. Geocichla sibirica.}

Accidental winter visitor; only one British record (Surrey). Breeds in East Siberia and Japan, wintering in China, Burma, and the adjacent islands. Japanese examples have less white on the underparts than continental ones.

\section{MISSEL-THRUSH. Turdus viscivorus.}

Resident. Breeds in North Africa, Europe south of the Arctic Circle, Persia, Turkestan, the North-west Himalayas, and South Siberia as far east as Lake Baikal. Migrates south from the coldest parts of its range in autumn. Eastern examples are large and pale.

\section{SONG-THRUSH. Turdus musicus.}

Common resident. Breeds in temperate Europe, and in South Siberia as far east as Lake Baikal. Winters in South Europe, North Africa, and South Persia.

\section{REDWING. Turdus iliacus.}

Common winter visitor. Breeds in aretic and subaretic Europe and Siberia as far east as Dauria. Winters in North Africa, South Europe, Persia, Russian Turkestan, and North-west India.

\section{AMERICAN ROBIN. Turdus migratorius.}

Accidental visitor; only one British record (Dublin). Summer visitor to Arctic America; resident in temperate North America; winter risitor to tropical North America. 

FIELDFARE. Turdus pilaris.

Common winter visitor. Breeds in arctic and subarctic Europe and Siberia as far east as Lake Baikal. Winters in North Africa, South Europe, Turkestau, and Cashmere.

BLACKBIRD. Merula merula.

Common resident. Breeds in Europe south of the Arctic Circle, North Africa, Asia Minor, Persia, Turkestan, Afghanistan, and Cashmere. Most northern birds migrate south in autumn. Eastern examples are larger than western ones.

\section{RING-OUZEL. Merula torquata.}

Summer visitor to our wildest moors. Breeds on most rocky mountains of Europe. Winters in North Africa, South Europe, Asia Minor, and Persia. Eastern examples differ slightly from western ones.

\section{BLACK-THROATED OUZEL. Merula atrigularis.}

Accidental winter visitor; only two British records (Sussex, Perth). Breeds in the valleys of the Obb and the Yenesei south of the Aretic Circle, the mountains of Russian Turkestan, and Cashmere. Winters in the plains of Russian and Chinese Turkestan and North India.

\section{COMMON DIPPER. Cinclus aquaticus.}

Commen resident on momtain streams. Resident in subaretic and subtropic Europe, Asia, and North Africa. Subject to much local variation. Typical form resident also in France, the Netherlands, and North Germany.

BLACK-BELLIED DIPPER. Cinclus aquaticus melanogaster.

Accidental visitor; one or two English and one Irish record. Aretic race of the Common Dipper, breeding in Scandinavia and on the mountains of West Europe.

\section{ROBIN. Erithacus rubecula.}

Common resident. Breeds in the Azores, temperate Europe, Nurth Afriea, and South Persia, migrating in autumn where the winters are severe as far as the confines of the Tropics. 



\section{ARCTIC BLUE-THROATED ROBIN. Erithacus suecica.}

Rare spring and antumn migrant (in Scotland three records only, in Ireland none). Breeds in the Aretic Regions of Europe and Siberia, and in the Pamir. Winters in North-east Africa and tropical Asia.

\section{NIGHTINGALE. Erithacus luscinia.}

Common summer visitor to England only, as far north as Yorkshire and as far west as Devonshire. Breeds in Palestine, Asia Minor, South Europe, and North-west Africa. Winters in Central Africa.

\section{ROCK-THRUSH. Monticola saxatilis.}

Accidental visitor; one British record (Hertfordshire). Breerls in North Africa, South Europe, Persia, Turkestam, South Siberia as far east as Lake Baikal, and North China. Winters in West Africa, Abyssinia, the base of the Himalayas, and the mountains of North China.

\section{REDSTART. Ruticilla phœnicurus.}

Summer visitor (very rare in Ireland). Brecds in Europe south of the Aretic Circle, and in South Siberia as far east as the Yenesei. Winter's in North Africa, Palestine, and Persia.

BLACK REDSTART. Ruticilla tithys.

Frequent winter visitor to the south of England; much rarer in Scotland and Ireland. Resident from the basin of the Mediterrancan castward to Persia. Summer visitor to Central Europe, wintering in Nubia.

\section{WHEATEAR. Saxicola œnanthe.}

Common summer visitor. Nearly circumpolar, brecding from Labrador, Greenland, and Iceland, across Europe and Siberia to Alaska. Winter range extends from the Bermudas and the Azores across North Africa to Persia, North India, Mongolia, and North China. 



\section{DESERT WHEATEAR. Saxicola deserti.}

Accidental winter visitor; three records (Sterling, Yorkshire, Forfar). Resident in North Africa, Arabia, and Persia. Summer visitor to Russian Turkestan and the Pamir, wintering in Baluchistan, Sind, and North-west India.

BLACK-THROAT'ED CHAT. Saxicola stapazina.

Accidental visitor; only one British record (Lancashire, eastern form). Brecds in South Europe, Asia Minor, and Persia, wintering in tropical Africa. Eastern examples have more black on the throat than western ones.

\section{ISABELLINE CHAT. Saxicola isabellina.}

Accidental visitor; only one British record (Cumberland). Summer visitor to South Russia, Asia Minor, Turkestan, Dauria, and Mongolia; wintering in North-west India, North China, and North-east Africa, many remaining to breed on the mountains near its winter-quarters.

\section{WHINCHAT. Pratincola rubetra.}

Common summer visitor; rare in Scotland, very rare in Ireland. Summer visitor to Europe sonth of the Arctic Cirele and Asia Minor, wintering in Africa north of the Equator.

\section{STONECHAT. Pratincola rubicola.}

Common resident. Resident in South Europe and Asia Minor. Summer visitor to Central Europe. Winter visitor to North Africa and Palestine. East of the Volga represented by a very close ally.

\section{HEDGE-SPARROW. Accentor modularis.}

Common resident. Summer visitor to subaretic Europe; resident in Central Europe; winter visitor to Sunth Europe, Asia Minor, and Palestine, occasionally wandering as far as North Africa. 

ALPINE ACCENTOR. Accentor alpinus.

Accidental visitor to England (a dozen records). Resident on the mountain ranges of South Europe, Asia Minor, Persia, and Russian 'Turkestan. Eastern examples are paler than western ones.

\section{SPOTTED FLYCATCHER. Muscicapa grisola.}

Common summer visitor. Breeds in Europe up to the Arctic Circle, Asia Minor, Persia, Turkestan, South Siberia as far east as Lake Baikal, and in the extreme north of India. Winters in North-west India and throughout Africa, a few remaining to breed in Algeria.

\section{PIED FLYCATCHER. Muscicapa atricapilla.}

Local summer visitor, very rare in Ireland. Breeds in Europe, to lat. $69^{\circ}$ in Scandinavia, but only to $60^{\circ}$ in East Russia, and in North Persia, wintering in North Africa, a few remaining to breed in Algeria.

\section{RED-BREASTED FLYCATCHER. Muscicapa parva.}

Accidental winter visitor; five English and two Irish records. Summer visitor to Central and South-cast Europe, North Persia, Russian Turkestan, and South-west Siberia. Winter visitor to North Africa, South Persia, and India.

\section{Subfamily SYLVIINÆ.}

GRASSHOPPER WARBLER. Locustella locustella.

Summer visitor. Brecls in Russia south and west of St. Petersburg, and in Central and West Europe. Winters in Spain, Morocco, Algeria, and Italy, a few remaining to breed in its winter-cjuarters.

\section{SAVI'S WARBLER. Locustella luscinioides.}

Formerly a summer visitor to the fens of Norfolk, Huntingdon, and Cambridge, but none seen since 1856. Breeds in Spain, France, Holland, Italy, Austria, South Russia, Persia, and Russian Turliestan. Winters in North Africa, some remaining to breed in Algeria. 

SEDGE-WARBLER. Acrocephalus phragmitis.

Common summer visitor. Breeds in North and Central Europe, and in Siberia as far east as the valley of the Yenesei. Winters throughout Africa and Asia Minor.

AQUATIC WARBLER. Acrocephalus aquaticus.

Accidental visitor; three British records (Sussex, Leicester, Kent). Breeds in Europe south of the Baltic, wintering in the basin of the Mediterranean, where a few remain to breed.

GREAT REED-WARBLER. Acrocephalus turdoides.

Accidental visitor; three British records (Kent, Hampshire, Northumberland). Breeds in Algeria, Europe south of the Baltic, Asia Minor, Palestine, North Persia, and Russian Turkestan. Winters in Sout? Africa.

\section{REED-WARBLER. Acrocephalus arundinaceus.}

Common summer visitor to England, of doubtful occurrence in Scotland or Ireland. Breeds in Central and Southern Europe, Asia Minor, Palestine, Persia, Russian Turkestan, and South-west Siberia. Winters in Central Africa.

\section{MARSH-WARBLER. Acrocephalus palustris.}

Very local summer visitor to the south of England. Breeds in Enrope east of Spain and south of the Baltic, Persia, Russian Turkestan, and South-west Siberia. Winters in Central and East Africa, from Egypt to Natal.

\section{ICTERINE WARBLER, Hypolais hypolais.}

Accidental visitor; only five British records (4 English, 1 Irish). Breeds in Europe west of Spain and south of the Arctic Circle, and South Siberia as far east as Omsk. Winters in South Africa. 

BARRED WARBLER. Sylvia nisoria.

Accidental visitor, seven British records (5 English, 1 Scotch, 1 Irish). Breeds in Europe east of the Rhine and south of St. Petersburg, Persia, and Turkestan as far east as Yarkand. Winters in Central Africa.

\section{ORPHEAN WARBLER. Sylvia orpheus.}

Accidental visitor, only two British records (Yorkshire, Middlesex). Breeds in Algeria, Central and Southern Europe, Asia Minor, Palestine, Persia, and Russian Turkestan. Winters in North Africa and Northwest India. Eastern examples have large bills.

\section{BLACKCAP. Sylvia atricapilla.}

Summer visitor (occasionally remaining to winter); rare in Scotland, rarer in Ireland. Breeds in the Azores, Canaries, Europe south of the Aretic Circle, Asia Minor, Palestine, and West Persia. Winters in South Europe and North Africa.

\section{GARDEN WARBLER. Sylvia hortensis.}

Summer visitor, rare and local in Ireland. Breeds in Europe south of the Aretic Circle, North Persia, South-west Siberia. Winters in tropical and Southern Africa.

\section{WHITETHROAT. Sylvia cinerea.}

Common summer visitor. Breeds in Algeria, lurope south of the Arctic Circle, Asia Minor, Palestine, Persia, Russian Turkestan, and South-west Siberia. Winters in Africa.

\section{DARTFORD WARBLER. Sylvia provincialis.}

Local resident in the south of England; unknown in Scotland or Ireland. Resident in the south of France, Spain, Morocco, Algeria, Corsica, Sardinia, Italy, Sicily, Egypt, and Palestine. 



\section{LESSER WHITETHROAT. Sylvia curruca.}

Local summer visitor; in Ireland only one record. Brects in Algeria, Europe, and Siberia up to the Arctic Circle, Asia Minor, North Persia, Turkestan, Mongolia, and North-east China. Winter's in North tropical Africa, India, and Ceylon. Eastern examples differ from western ones.

\section{RUFOUS WARBLER. Sylvia galactodes.}

Accidental visitor; only three British records (Sussex, Devon), all of the rufous form. Breeds in the basin of the Meditermean, Persia, and Russian Turkestan. Winters in Baluchistan, North-west India, and North Africa. Eastern examples are greyer than western ones.

\section{WOOD-WREN. Phylloscopus sibilatrix.}

Summer visitor; very rare in Ireland. Breeds in Central and Southeast Europe. Winters in North Africa, where a few remain to breed on the Atlas Mountains.

\section{WILLOW-WREN. Phylloscopus trochilus.}

Common summer visitor. Brecds in aretic and subarctic Europe, and Siberia as far east as the Yenesci. Winters in Persia, the basin of the Mediterrancan (where a few remain to breed), and throughout Africa.

\section{CHIFFCHAFF. Phylloscopus rufus.}

Common summer visitor. Breeds in Europe as far north as Archangel and as far east as the Volga, but very sparingly south of the Rhone and the Danube, whence its winter-quarters extend to the confines of tropical Africa.

YELLOW-BR0WED WILLOW-WREN. Phylloscopus superciliosus.

Accidental visitor, only four British records (Northumberland, Gloucester, Shetland, Kerry). Breeds in the pine-forests of Easteru Sibria ; wintering in South China, Assam, Burma, and North-cast India. 



\section{Subfamily PARINE.}

\section{GOLDCREST. Regulus cristatus.}

Common resident. Breeds in Europe south of latitude $60^{\circ}$, and in Asia Minor, Turkestan, South Siberia, the Himalayas, North China, and Japan. Migrates south in autumn where the winters are cold. Eastern examples differ slightly from western ones.

\section{FIRECREST. Regulus ignicapillus.}

Rare winter visitor to Fingland (Scotch and Irish records doubtful). Breeds in Central and Southern Europe west of the Volga, Algeria, and Asia Minor. Migrates south in autumn where the winters are cold.

\section{GREAT TIT. Parus major.}

Common resident. Breeds in Western Lurope and Africa, from the Aretie Circle to the Canary Islands; thence eastwards across Southern Russia, Asia Minor, Palestine, and Persia to Southern Siberia. Migrates south in very cold winters.

\section{BLUE TIT. Parus cæruleus.}

Common resident. Breeds in Europe in Scandinavia up to lat. 64. but in East Russia only to $61^{\circ}$, and in Asia Minor. Migrates south in autumn from the coldest parts of its range, but does not cross the Mediterrancan.

\section{COAL TIT. Parus ater.}

Rare winter visitor. Resident in Europe south of the Aretic Circle, Asia Minor, South Siberia, Japan, and North China. Lastern examples differ slightly from western ones.

\section{BRITISH COAL TIT. Parus ater britannicus.}

Common resident, peculiar to the British Islands, but intergrading with the typical form, in which the upper parts are slate-grey, whereas in British examples they are gencrally olive-brown. 

MARSH-TIT. , Parus palustris.

Resident in England and South Scotland, occasionally visiting North Scotland and East Ireland. Resident in Europe, Asia Minor, South Siberia, North China, and Japan. Subject to considerable climatic variation.

\section{CRESTED TIT. Parus cristatus.}

Local resident in North Scotland; accidental visitor to the rest of Great Britain; of doubtful occurrence in Ireland. Resident in Europe south of latitude $64^{\circ}$ and west of the Volga.

\section{LONG-TAILED TIT. Acredula caudata.}

Accidental visitor; only one British record (Northumberland). Resident in Europe north of the Alps and sonth of the Aretic Circle, Sonth Siberia, Manchuria, and the north island of Japan. Subject to slight local variation.

BRITISH LONG-TAILED TIT. Acredula rosea.

Common resident. Resident in the Netherlands, West Germany, and North France. Is said to intergrale with the continental species, but the supposed intermediate forms may possibly be immature birds.

\section{BEARDED TIT. Panurus biarmicus.}

Local resident in the fens of England. Breeds in Europe south of the Baltic, Turkestan, South-west Siberia, and North-castern Tibet. Migrates south in autumn from the northern parts of its range.

\section{WREN. Troglodytes parvulus.}

Common resident. Resident in Algeria, Europe sonth of the Aretic Regions, Asia Minor, North Persia, Russian Turkestan, and Sonth Siberia. Subject to considerable local variation. 

ST.-KILDA WREN. Troglodytes parvulus hirtensis.

Local race of the Common Wren, peculiar to St. Kilda. Is paler in colour, more barred on the upper parts, and has a larger bill and hallux than the typical form.

\section{COMMON CREEPER. Certhia familiaris.}

Resident across Europe, Asia, and America between the Aretic Regions and the Tropics, in Scandinavia to $63^{\circ}$ north latitude, but in Siberia only to $57^{\circ}$, and in America only to $50^{\circ}$. Subject to some climatic variation.

\section{WALL-CREEPER. Tichodroma muraria.}

Accidental visitor; only two British records (Norfolk, Lancashire). Resident in mountainous districts across Lurope and Asia between $30^{\circ}$ and $50^{\circ}$ north latitude.

\section{NUTHATCH. Sitta cæsia.}

Common resident in England, very rare in Scotland, unknown in Ireland. Resident in Europe and Asia from the Arctic Circle to the confines of the Tropics. Subject to much climatic variation.

\section{Subfamily CORVINÆ.}

\section{RAVEN. Corvus corax.}

Resident in ever-decreasing numbers. Resident across Europe, Asia Minor, Persia, Russian Turkestan, Siberia, and Manchuria. Breeds in Cashmere, wintering in the Punjab. Resident in North America.

\section{CARRION-CROW. Corvus corone.}

Resident in England and South Scotland, very rare in Ireland. Breeds in Lurope west of the Elbe, the valley of the Danube, the northern shores of the Black Sea, the Caucasus, Russian Turkestan, East Siberia, Manchuria, and Japan. Migrates south from the coldest parts of its range. 



\section{H00DED CROW. Corvus corone cornix.}

Resident in North Scotland and Ireland; winter visitor to South Scotland and England. Breeds in Europe east of the Elbe, and Siberia west of the Lena, Asia Minor, Palestine, Egypt, Persia, and Turkestan. Migrates from the coldest parts of its range to Spain and North Africa.

R00K. Corvus frugilegus.

Common resident. Breeds in North Europe and West Siberia south of the Arctic Circle. Winters in Algeria, South Europe, Asia Minor, North Persia, Cashmere, and North-west India.

\section{JACKDAW. Corvus monedula.}

Common resident. Resident in Algeria, Asia Minor, Palestine, Russian 'Turkestan, and from West Europe (south of lat. $66^{\circ}$ ), across West Siberia to the Valley of the Yenesei (south of lat. $56^{\circ}$ ). Summer visitor to Afghanistan and Cashmere, wintering in North-west India.

\section{MAGPIE. Pica caudata.}

Common resident. Breeds as far north as the Aretic Circle in Europe, Siberia, and North America as far east as the Missouri. Its southern range extends to the confines of the Tropics. Subject to some local variation. Migrates south from its coldest breeding-grounds in autumn.

\section{COMMON JAY. Garrulus glandarius.}

Common resident; very local in Scotland and Ireland. Ranges across Europe, Siberia, and Manchuria to Japan, only reaching the Arctic Circle in Seandinavia. Migratory in the extreme north. Subject to some local variation. 

CHOUGH. Pyrrhocorax graculus.

Local resident on our rocky coasts. Resident very locally on the coast from Brittany to the Canarics; and on the principal mountain-ranges of North Africa, Europe, and across the centre of Asia to the Pacific. Subject to some local variation.

\section{ALPINE CHOUGH. Pyrrhocorax alpinus.}

Supposed accidental visitor; only one British record (Oxfordshire). Resident on the highest mountains of Spain and Central Europe, whence its range exteuds across Central Asia to the mountains of North-west China.

\section{NUTCRACKER. Nucifraga caryocatactes.}

Accidental visitor; about a score English records, two Scotch, but no Irish. Resident in the aretic pine-forests of Lurope and Asia from the sierras of Spain to the mountains of Japan and North China. Subject to some local variation.

\section{GOLDEN ORIOLE. Oriolus galbula.}

Irregular summer visitor to England, accidental visitor to Scotland and Ireland. Breeds in Algeria, Europe south of the Baltic, Persia, Russian Turkestan, and South Siberia as far east as the Altai range. Winters in Africa as far south as Natal and Damara Land.

\section{Subfamily LANIINÆ.}

\section{GREAT GREY SHRIKE. Lanius excubitor.}

Rare winter visitor. Breeds in Europe north of the $\Lambda l p$ s and south of the Arctic Circle. From the coldest parts of its range migrates in autumn to Asia Minor. 

PALLAS'S GREY SHRIKE. Lanius major.

Accidental visitor, but of frequent occurrence. Breeds in South Siberia and Manchuria, some remaining to winter. Winters also in Turkestan. Has only one white bar across the wing.

\section{LESSER GREY SHRIKE. Lanius minor.}

Accidental visitor; only four British records (Cornwall, Devon, Suffolk). Breeds in Central and South-cast Europe, Asia Minor, Palestine, Persia, and South-west Siberia. Winters in the Nile valley and South Africa as far south as Damara Land.

RED-BACKED SHRIKE. Lanius collurio.

Summer visitor; very rare in Scotland; only one Irish record. Breeds in Central and Southern Europe, Asia Minor, North Persia, Russian Turkestan, and South-west Siberia. Winters in Southern Africa.

WOODCHAT SHRIKE. Lanius rufus.

Accidental visitor to England; about thirty records; no Scotch or Irish record. Breeds in Central and Southern Europe, Asia Minor, Palestine, and Persia. Winters in Central Africa.

\section{Subfamily AMPELIN 死.}

WAXWING. Ampelis garrulus.

Irregular winter visitor; sometimes in great numbers. Circumpolar species, breeding in the Aretic pine-forests of Europe, $\Lambda$ sia, and America. Wanders south in winter, but not as far as the Tropics. 



\section{Subfamily STURNIN死.}

\section{STARLING. Sturnus vulgaris.}

Common resident. Breeds in the Azores and across Central Europe, Persia, Turkestan, and South Siberia to the sources of the Amoor. Winters in the basin of the Mediterranean and in India. Subject to some local variation.

\section{ROSE-COLOURED STARLING. Pastor roseus.}

Accidental visitor, but of frequent occurrence. Breeds irregularly in great colonies in Italy, Turkey, Asia Minor, South Russia, Turkestan, and South-west Siberia. Winters in India.

\section{RED-WINGED STARLING. Agelæus phœniceus.}

Supposed accidental visitor; a dozen records, probably of escaped birds. Breeds throughout North America as far north as the Great Slave Lake. From the coldest part of its range migrates south in autumn.

\section{Subfamily ICTERINÆ.}

RUSTY GRAKLE. Scolecophagus ferrugineus.

Supposed accidental visitor; only one British record (Glamorgan). Breeds in arctic America up to the limit of forest-growth. Winters in the Southern States.

AMERICAN MEADOW-STARLING. Sturnella magna.

Supposed accidental visitor; three British records (Norfolk, Suffolk, Gloucester), possibly of escaped birds. Breeds in the Eastern States of North America. Migrates south in autumn from the coldest parts of its range. 



\section{Subfamily ALAUDINÆw.}

W00D-LARK. Alauda arborea.

Local resident. Breeds locally in Central Europe. Winters in South Europe, Asia Minor, and North-west Persia, a few remaining to breed in the mountains.

CRESTED LARK. Alauda cristata.

Accidental visitor; eight or ten occurrences on the south coast of England. Resident in Algeria, Central and Southern Europe, Asia Minor, Palestine, Persia, Russian 'Turkestan, and North-west India.

\section{SKY-LARK. Alauda arvensis.}

Common resident. Breeds across Europe and Sibcria south of the Aretie Regions, and at high elevations in North-west Africa, Turkestan, Persiat, and Japan. Winters in North Afriea, Asia Minor, North-west India, and North China. Subject to some climatic variation.

SHORT-T0ED LARK. Alauda brachydactyla.

Accidental visitor; nine British records, all south coast of England except one Suffolk and one Mayo. Breeds in Nortll-west $\Lambda$ frica, South Europe, Persia, Russian Turkestan, and South-west Sibcria. Winters in North Africa and India.

\section{WHITE-WINGED LARK. Alauda sibirica.}

Accidental visitor; only one British record (Sussex). Resident in South-cast Russia. Brecds in South-west Siberia, wintering in Russian T'urkestan.

\section{SHORE-LARK. Alauda alpestris.}

Irregular winter visitor to England and Scotland. Circumpolar species, breeding in the Aretic Regions of both Continents; wandering south in winter, but not as far as the Tropies. 



\section{Subfamily FRINGILLINE.}

COMMON CROSSBILL. Loxia curvirostra.

Local resident. Breeds in most of the subarctic pine-forests of Northrrest Africa, Europe, Siberia, Manchuria, and Japan. Wanders irregularly in hard winters to the nearest temperate elimates. Doubtfully distinct allies in Canada and Mexico.

PARROT CROSSBILL. Loxia curvirostra pityopsittacus.

Rare winter visitor. Breeds in Scandinavia, the Baltic Provinces, and North Germany, wandering irregularly in hard winters to the nearest temperate climates.

AMERICAN WHITE-WINGED CROSSBILL. Loxia leucoptera.

Accidental visitor; three British records (Worcester, Devon, Norfolk). Breeds in the arctic pine-forests of North America, wandering irregularly in hard winters into the Northern States.

WHITE-WINGED CROSSBILL. Loxia leucoptera bifasciata.

Rare winter visitor. Breeds in the pine-forests near the Aretic Circle in Europe and Siberia, wandering irregularly in hard winters to the nearest milder climate.

\section{PINE-GROSBEAK. Carpodacus enucleator.}

Rare winter visitor; only half a dozen records (all English). Circumpolar species, brecding in the arctic pine-forests of both Continents. Wanders south in winter into the temperate regions.

SCARLET ROSE-FINCH. Carpodacus erythrinus.

Accidental visitor; only two British records (Sussex, Mirldlesex). Breeds in subarctic Europe, as far west as the Baltic, and Siberia, and at high elevations as far south as Asia Minor and North China. Winters in India and Burma. 

BULLFINCH. Pyrrhula vulgaris.

Resident. Breeds in North Europe and Siberia up to the Aretic Circle. Winters in South Europe, Turkestan, and South Siberia. West European examples are smaller and duller than eastern examples.

\section{HAWFINCH. Coccothraustes vulgaris.}

Local resident in England, accidental visitor to Scotland and Ireland. Breeds locally in North-west Africa, and across Europe, Asia Minor, and Siberia south of lat. $60^{\circ}$. Winters in the southern portion of its breedingrange, and in North China and Japan.

\section{HOUSE-SPARROW. Passer domesticus.}

Common resident. Resident in Europe and West Siberia up to the Arctic Circle (with the exception of Italy and the islands west of it), North Africa, Asia Minor, Persia, India, and Burma. Tropical examples differ slightly.

\section{TREE-SPARROW. Passer montanus.}

Local resident, very rare in Ireland. Resident in Europe and Asia south of the Arctic Circle, except in Greece, Asia Minor, Palestine, Central and Southern Persia, and India south of the Himalayas.

\section{GREENFINCH. Fringilla chloris.}

Common resident. Breeds in Europe south of the Aretic Regions, in North-west Africa, Asia Minor, North-west Persia, and North-west Turkestan. Migrates southwards from the coldest parts of its breeding-range in winter. Subject to some local variation. 

CANARY. Fringilla canaria.

Supposed accidental visitor; a dozen or more occurrences on the south coast of England. Resident on the Azores, Madeira, and most of the Canary Islands.

\section{SERIN FINCH. Fringilla serinus.}

Supposed accidental visitor; a dozen or more occurrences on the south coast of England. Breeds in Central and Southern Europe and in Asia Minor. Winters in Algeria, where a few remain to breed, and in Palestine and Egypt.

\section{SISKIN. Fringilla spinus.}

Winter visitor, a few remaining to breed. Breeds in subaretic Europe and North Persia, wintering in the basin of the Mediterranean. Also breeds in Manchuria and Japan, wintering in South China. Supposed to be absent from the intervening district.

\section{GOLDFINCH. Fringilla carduelis.}

Local resident. Breeds in Europe and Siberia, not ranging to the Arctic Regions nor east of the Yenesei. Resident in North-west Africa, Asia Minor, and Persia. Winters in Egypt and Russian Turkestan. Subject to some local variation.

\section{BRAMBLING. Fringilla montifringilla.}

Winter visitor. Breeds in the subarctic birch-forests of Europe and Sibcria, wandering in winter to South Europe, Algeria, Asia Minor, Turkestan, the Himalayas, China, and Japan.

CHAFFINCH. Fringilla cœlebs.

Common resident. Breeds in North Europe (above the Arctic Circle in Norway), South-mest Siberia, and at high elevations in Algeria, South Europe, Asia Minor, Palestine, and West Persia. Winters in the southeris parts of its breeding-rauge and in Russian Turkestan and Egypt. 



\section{TWITE. Fringilla flavirostris.}

Resident on most of our wildest moorlands. Breeds in the alpine and subalpine districts of Norway, wintering in Central Europe south of the Baltic and west of Russia.

\section{LINNET. Fringilla cannabina.}

Resident. Breeds in Scandinavia up to lat. $64^{\circ}$ and in East Russia and West Siberia up to lat. $52^{\circ}$. Resident south of the Baltic, in Northwest Africa, Asia Minor, and Russian Turkestan. Winters in Egypt, Abyssinia, and Cashmere. Eastern examples are large and brilliant.

\section{MEALY REDPOLE. Fringilla linaria.}

Irregular winter visitor to England and Scotland (only two Irish records). Circumpolar species, breeding in the Arctic Regions of both continents. Wanders in winter to the confines of the Tropics. Subject to much climatic variation.

LESSER REDPOLE. Fringilla linaria rufescens.

Local resident, principally confined to the British Islands. Breeds on some of the mountains of Western Europe, wandering in winter to the adjacent countries.

GREENLAND REDPOLE. Fringilla linaria hornemani.

Accidental visitor, only one British record (Northumberland). Breeds in the Aretic Regions of North-east America, Greenland, Iceland, and Spitzbergen, wandering irregularly south in winter.

SNOW-BUNTING. Emberiza nivalis.

Irregular winter visitor, a few remaining to brced in Scotland. Circumpolar species, breeding in the Aretic Regions, wandering irregularly int the temperate region in winter. 

LAPLAND BUNTING. Emberiza lapponica.

Irregular winter visitor, about forty British records, including two Scotch and one Irish. Circumpolar species, breeding in the Arctic Regions, wandering in winter into the Temperate Regions and sometimes to the confines of the Tropics.

\section{REED-BUNTING. Emberiza schœniclus.}

Common resident. Breeds in Europe and Siberia up to the limit of forest-growth. Migrates in autumn from the coldest parts of its range to North Africa, Greece, Asia Minor, 'Turkestan, China, and Japan. Subject to some local variation.

\section{RUSTIC BUNTING. Emberiza rustica.}

Accidental visitor; only three British records (Sussex, Yorkshire, Herts). Breeds in subarctic Siberia and Europe, as far west as the Baltic. Winters in China and Japan, and probably in Russian Turkestan.

LITTLE BUNTING. Emberiza pusilla.

Accidental visitor, only one British record (Sussex). Brecds in the Arctic Regions of Siberia and Europe as far west as Archangel. Winters in North India, Burma, and China.

\section{CORN-BUNTING. Emberiza miliaria.}

Resident. Summer visitor to Central Europe, wintering in Egypt, Nubia, Arabia, and Sind. Resident in the Canaries, North-west Africa, South Europe, Asia Minor, Palestine, North Persia, and Russian Turkestan.

\section{ORTOLAN BUNTING. Emberiza hortulana.}

Rare winter visitor; a score records, including two Scotch and onc Irish. Breeds in Europe and West Siberia (in Norway up to lat. $67^{\circ}$, further east to $57^{\circ}$ ), Asia Minor, Persia, and Russian Turkestan. Winters in Central Africa and occasionally in the north of Cashmere. 



\section{CIRL BUNTING. Emberiza cirlus.}

Resident in South England; three Scotch records, no Irish. Breeds in Central and Southern. Europe, as far north as Dresden and as far east as the Crimea and West Asia Minor. Migrates from the coldest part of its range to winter in North-west Africa, where a few breed.

\section{YELLOW HAMMER. Emberiza citrinella.}

Common resident. Breeds in Europe and West Siberia up to lat. $70^{\circ}$ in Scandinavia, and $64^{\circ}$ in Siberia. Resident in Central Europe. Winter visitor to South Europe, Asia Minor, North Persia, and North-west Turkestan.

\section{BLACK-HEADED BUNTING. Emberiza melanocephala.}

Accidental visitor; only three British records (Sussex, Notts, Fife). Summer visitor to Italy, Greece, Turkey, Palestine, Asia Minor, South Russia, and Persia; wintering in Western and Central India.

\section{BRANDT'S SIBERIAN BUNTING. Emberiza cioides.}

Supposed accidental visitor; only one British record (Yorkshire). Resident in South-east Siberia, Manchuria, and North China. Chinese examples are smaller than those from Siberia.

\section{Subfamily MOTACILLINÆE.}

PIED WAGTAIL. Motacilla yarrelli.

Common resident. Breeds in South-west Norway, Holland, and Northwest France; wintering in South-west France, Spain, Portugal, Morocco, and occasionally in Italy.

\section{WHITE WAGTAIL. Motacilla alba.}

Rare summer visitor; very rare in Ireland. Breeds throughout Europe and Siberia as far east as Lake Baikal. Resident in the basin of the Mediterranean. Winter visitor to Tropical Africa, India, Burma, and West China. Eastem examples differ slightly from westem ones. 

GREY WAGTAIL, Motacilla boarula,

Local resident. Breels in the Azores, Canaries, Central and Southern Europe, Asia Minor, Persia, Turkestan, Cashmere, South Siberia, and Japan. Winters in the basin of the Mediterranean, India, Burma, and China. Eastern examples have generally shorter tails than western ones.

\section{BLUE-HEADED WAGTAIL. Motacilla flava.}

Rare summer visitor; very rare in Scotland, of doubtful occurrence in Ireland. Breeds in subaretic and temperate Europe, South Siberia, Mongolia, North China, and Alaska. Winters in South Africa, India, and Burma. Subject to some local variation.

\section{YELLOW WAGTAIL, Motacilla raii.}

Summer visitor; rare in Scotland, very rare in Ireland. Breeds in West France and in the basin of the Caspian. Winters in South Africa. Eastern birds supposed to differ slightly from western ones.

TREE-PIPIT, Anthus arboreus.

Summer visitor; local in Scotland, unknown in Ireland. Breeds in Europe and West Siberia, in Norway to lat. $69^{\circ}$, but in the valley of the Yenesei to $62^{\circ}$. Winters in South Europe, Africa north of the equator, and in North-west India.

\section{MEAD0W-PIPIT. Anthus pratensis.}

Common resident. Breeds in Europe from the North Cape to the Alps and the Pyrenees. Winters on both shores of the Mediterranean, and in the South-west of Russian Turkestan. 



\section{RED-THR0ATED PIPIT. Anthus cervinus.}

Accidental visitor; only three British records (Shetland, Sussex, Kent). Breeds in the Arctic Regions of Europe and Asia. Winters in Northeast Africa, Persia, India, Burma, South China, and Borneo.

\section{RICHARD'S PIPIT. Anthus richardi.}

Irregular winter visitor; sixty English records, one Scotch, no Irish. Breeds in the centre of Asia to lat. $58^{\circ}$ in the valley of the Yenesei, to the confines of China in the east, and to the foot of the Pamir in the west and south. Winters in India, Ceylon, Burma, and South China.

TAWNY PIPIT. Anthus campestris.

Winter visitor; a score English records, no Irish or Scotch. Breeds in Algeria, Europe up to lat. 57 , Asia Minor, Russian Turkestan, and South-west Siberia. Winters in North Africa, South Persia, and Northwest India. Eastern examples are smaller than western ones.

\section{ROCK-PIPIT. Anthus obscurus.}

Common resident on the coast. Breeds on the west coast of Europe from the White Sea to the Bay of Biscay. Is resident except in the Arctic Regions. Subject to some local variation.

\section{ALPINE PIPIT. Anthus spinoletta.}

Accidental visitor; four British records (all Sussex). Circumpolar species, breeding on the mountains and wintering in the plains of temperate Europe, Asia, and America, migrating from the coldest parts of its range to the confines of the Tropics. Subject to local variation. 



\section{Subfamily HIRUNDININÆ.}

\section{BARN-SWALLOW. Hirundo rustica.}

Common summer visitor. Breeds in North Africa, Europe south of lat. $68^{\circ}$, Siberia south of lat. $60^{\circ}$, Japan, Palestine, Asia Minor, Persia, and the extreme north of India. Winters in Africa south of the Atlas, India, and Burma. Eastern examples differ slightly from western ones.

\section{HOUSE-MARTIN, Chelidon urbica.}

Common summer visitor. Breeds in North Africa, Europe south of lat. $71^{\circ}$ in Scandinavia, West Siberia south of lat. $66^{\circ}$, Palestine, Asia Minor, Persia, and North-west India. Winters in Central Africa and Western India.

\section{SAND-MARTIN. Cotyle riparia.}

Common summer visitor. Circumpolar species, breeding from the confines of the Tropics to a few degrees above the Aretic Circle, and wintering in the Tropics of both hemispheres.

\section{PURPLE MARTIN. Progne purpurea.}

Supposed accidental visitor; four records (three English, one Irish), but none satisfactory. Breeds in the United States and Canada up to lat. $68^{\circ}$. Winters in Mexico.

\section{Suborder SCANSORES.}

\section{Family PICID正.}

\section{GREAT SPOTTED WOODPECKER. Picus major.}

Local resident in England, rare visitor to Scotland and Ireland. Resirlent in the Canaries, Europe south of the Arctic Circle, Asia Minor, Siberia up to about lat. $60^{\circ}$, and Japan. Subject to some local variation. 



\section{LESSER SPOTTED WOODPECKER. Picus minor.}

Local resident in England; very rare visitor to south Scotland and Ireland. Resident in the Azores, Algeria, Europe, Asia Minor, Siberia, and the North Island of Japan, nearly up to the limit of forest-growth. Subject to much local variation.

\section{GREEN WOODPECKER. Gecinus viridis.}

Resident in England; rare accidental visitor to Scotland and Ireland. Resident in Europe south of lat. 63․ Asia Minor, and West Persia. Subject to some local variation.

\section{WRYNECK. Iynx torquilla.}

Summer visitor to England; rare visitor to Scotland; only two Irish records. Resident in Algeria. Summer visitor to Europe south of lat. (6.t, Asia Minor, Palestine, Turkestan, South Siberia, the ILimalayas, and Japan. Winter visitor to Central Africa, India, Burma, and South China.

\section{Order CORACIIFOR MES.}

Suborder PICARIE. Family CYPSELID仺.

COMMON SWIFT. Cypselus apus.

Common summer visitor. Summer visitor to the Canaries, North Africa, Europe south of lat. $69^{\circ}$, Palestine, Asia Minor, Persia, Turkestan, Cashmere, Siberia south of lat. 50 $0^{\circ}$, Mongolia, and North China. Winter visitor to Africa south of the Sahara, North-west India, and China.

\section{ALPINE SWIFT. Cypselus melba.}

Accidental summer visitor to lingland and Ireland; a score or more records. Summer visitor to the alpine distriets of Central and Southern Europe, North Africa, Asia Minor, Palestinc, Persia, Russian Turkestan, and North India. Winter visitor to South Africa, India, and Ceylon. 



\section{NEEDLE-TAILED SWIFT. Chætura caudacuta.}

Accidental visitor; only two British records (Essex, Hampshire). Breeds in South-east Siberia, Mongolia, Tibet, North China, and Japan. Winters in East Australia and Tasmania.

\section{Family CAPRIMULGID $Æ$.}

COMMON NIGHTJAR. Caprimulgus europæus.

Summer visitor. Breeds in Europe south of lat. $63^{\circ}$, West Siberia south of lat. 59 $9^{\circ}$, North-west Africa, Palestine, Asia Minor, Persia, Russian Turkestan, and North-west India. Winters in Arabia and throughout Africa. Eastern examples are paler than western ones.

ISABELLINE NIGHTJAR. Caprimulgus ægyptius.

Accidental visitor; only one British record (Nottingham). Summer visitor to Russian Turkestan, Baluchistan, Egypt, and Nubia. Probably winters in Arabia and Central Africa. IIas once occurred on Heligoland, thrice on Malta, and once in Sicily.

RED-NECKED NIGH'JAR, Caprimulgus ruficollis.

Accidental visitor; only one British record (Northumberland). Breeds on the Canaries, in North-west Africa, and South Spain and Portugal. Winter-quarters unknown, but probably in North Africa.

\section{Family MEROPID蚱.}

\section{COMMON BEE-EATER. Merops apiaster.}

Accidental visitor; thirty to forty British records, mostly English. Summer visitor to the Canaries, North Africa, Europe south of the Carpathians, Palestine, Asia Minor, Persia, Russian Turkestan, and Cashmere. Winters in South Africa, where it is said that a few remain to breed. 



\section{Family CORACIIDÆ.}

\section{COMMON ROLLER. Coracias garrula.}

Very rare spring and autumu migrant. Summer visitor to North-west Africa, Europe south of lat. $60^{\circ}$, Palestine, Asia Minor, Persia, Russian Turkestan, South-west Siberia, and North-west India. Winter visitor to Arabia and Central and Southern Africa.

\section{Suborder HALCYONES.}

\section{Family ALCEDINIDÆ.}

\section{COMMON KINGFISHER. Alcedo ispida.}

Common resident. Resident in Africa, Europe, and Asia from lat. 55 to about lat. $20^{\circ}$ north. Eastern examples are smaller than western ones, and are found as far south as the Equator.

\section{BELTED KINGFISHER. Ceryle alcyon.}

Supposed accidental visitor ; two British records (both Irish). Summer visitor to Aretic America; resident in the rest of the North-American continent.

\section{Order CUCULIFORMES.}

\section{Suborder COCCYGES.}

\section{Family CUCULID压.}

\section{COMMON CUCK00. Cuculus canorus.}

Common summer visitor. Breeds in North Africa, Europe and Siberia almost up to the limit of forest-growth, Asia Minor, Persia, Turkestan, Mongolia, the Himalayas, North China, and Japan. Winters in Sonth Africa, India, Burma, and South China.

GREAT SPOTTED CUCK00. Cuculus glandarius.

Accidental visitor; only two British records (Galway, Northumberland). Brecds in the Spanish peuinsula, North Africa, Palestine, Asia Minor, aud Persia. Winters throughout Africa. 

YELLOW-BILLED CUCK00. Coccyzus americanus.

Accidental visitor; half a dozen British records (two Irish, two Welsh, two Cornish). Breeds across North America from South Canada to the Southern States. Winters in tropical America.

BLACK-BILLED CUCK00. Coccyzus erythrophthalmus.

Accidental visitor; ouly one British record (Belfast). Breeds in East North America from Labrador to Texas. Winters in Mexico, Central America, and the northern part of South America.

\section{Suborder UPUP王.}

\section{Family UPUPID疋.}

H00P0E. Upupa epops.

Irregular summer visitor. Breeds in Europe and Siberia south of lat. 56 ${ }^{\circ}$, Palestine, Asia Minor, Persia, Turkestan, Mongolia, and North China. Resident in North Africa, India, Ceylon, Burma, and South China. Winters in Central Africa north of the Equator and Madagascar.

\section{Order FALCONIFORMES.}

\section{Suborder COLUMBÆ.}

\section{Family COLUMBIDÆ.}

RING-DOVE. Columba palumbus.

Resident; numbers increased in autumn by migrants. Summer visitor to North Europe nearly up to the Arctic Circle; resident in Central and Southern Europe and North-west Africa. Occasional visitor to Southwest Siberia.

\section{STOCK-D0VE. Columba œnas.}

Local resident in Britain, rare in Scotland, confined to the north-east in Ireland. A resident in temperate Europe, North-west Africa, and Asia Minor, migrating south in autumn when the winters are severe. 

ROCK-DOVE. Columba livia.

Resident on all our rocky coasts. Local resident on rocky coasts and mountains south of the Aretic Circle, across Europe, North Africa, and North Asia. Subject to some local variation.

\section{TURTLE-DOVE. Turtur auritus.}

Common summer visitor to South England, rarer in North England, Wales, and Ireland, very rare in Scotland. Summer visitor to temperate Europe, North Africa, Asia Minor, Palestine, Persia, and Turkestan. Winter visitor to Central Africa.

\section{EASTERN TURTLE-DOVE. Turtur orientalis.}

Accidental visitor ; only one British record (Scarboro'). Summer visitor to South-east Siberia. Winter visitor to India, China, and Japan. Subject to some local variation.

\section{PASSENGER PIGEON. Ectopistes migratorius.}

Half a dozen examples have been shot in various parts of England, Scotland, and Ireland, probably escaped from confinement. Breeds in Canada south of the Arctic Circle and in the North-eastern States. Winters in the States.

\section{Suborder STRIGES.}

\section{Family STRIGIDÆ.}

\section{BARN-0WL. Aluco flammeus.}

Common resident. Circumtropical species, resident from about $40^{\circ}$ North to $40^{\circ}$ South, except that in West Europe it ranges to $58^{\circ}$ North. Subject to considerable local variation.

\section{W00D-0WL. Strix aluco.}

Resident in Great Britain, unknown in Ireland. Resident in Algeria, Europe to lat. $67^{\circ}$ in the west and $58^{\circ}$ in the east, Palestime, Asia Minor, Turkestan, the Himalayas, Tibet, and North China. 'T'wo forms-one grey, the other rufous,-probably climatic variations. 

LONG-EARED OWL. Strix otus.

Common resident. Breeds in the Azores, Canaries, North Africa, Europe south of the Arctic Circle, Palestine, Asia Minor, South Siberia, and the Himalayas. Winters in Persia, North India, North China, Japan, and the warmer parts of its breeding-range.

TENGMALM'S OWL. Strix tengmalmi.

Accidental visitor; a score British records (three Scotch, no Irish). Circumpolar species, breeding in the aretic pine-forests of both hemispheres, wandering irregularly in winter to the confines of the temperate regions.

SHORT-EARED OWL. Strix brachyotus.

Common winter visitor, a few remaining to breed. Circumpolar species, breeding in arctic and subarctic Europe, Asia, and America, wintering in the Tropics of the three continents, and breeding also in temperate South America. Subject to some climatic variation.

\section{LITTLE 0WL. Noctua noctua.}

Accidental visitor; a score Linglish records, probably most of them of caged birds. Resident in Central and Southern Europe and North Africa. Subject to some climatic variation.

\section{SNOWY 0WL. Surnia nyctea.}

Rare winter visitor. Circumpolar species, breeding on the fjelds of Lapland, the tundras of Russia and Siberia, and the barren grounds of Arctic America. Occasionally wander's southwards in hard winters.

\section{HAWK-0WL. Surnia funerea.}

Accidental winter visitor to England and Scotland (two records: Wiltshire, Shetland). Resident in the pinc-forests of Aretic Europe and Siberia. Subject to some climatic variation. 

AMERICAN HAWK-0WL. Surnia funerea hudsonia.

Accidental winter visitor to England and Scotland (half a dozen records). Resident in the pine-forests of Arctic America, a few straying in winter as far south as the Northern States.

EAGLE-0WL. Bubo maximus.

Accidental visitor to England and Scotland. Resident in the pineforests of Lurope, North Africa, and Asia as far south as Persia, the Himalayas, and North China. Subject to some climatic variation.

\section{SCOPS 0WL. Scops scops.}

Accidental risitor; a score records, including three Irish and one Scotch. Breeds in Algeria, Europe south of the Baltic, Asia Minor, Russian Turkestan, and Persia. Winters in the southern lialf of its breedingrange and in Central Africa north of the Equator.

\section{Suborler ACCIPITRES.}

\section{Family VULTURIDÆ.}

\section{GRIFFON VULTURE. Gyps fulvus.}

Accidental visitor; only one British record (Cork). Resident in South Europe, North Africa, and South-west Asia, as far east as Russian T'urkestan and North India.

EGYPTIAN VULTURE، Neophron percnopterus.

Accidental visitcr; two British records (Somerset and Essex). Summer visitor to South Europe, Persia, and Russian Turkestan. Resident in North Africa; winter visitor to South Africa. 



\section{Family FALCONID E}

BROWN JER-FALCON. Falco gyrfalco.

Accidental visitor; two authentic British records (Suffolk and Sussex). Resident on the Scandinavian fells, occasionally wandering south in winter. Subject to some local variation.

ICELAND JER-FALCON. Falco gyrfalco islandus.

Accidental visitor. Resident in Iceland and in South Greenland, occasionally wandering south in winter.

GREENLAND JER-FALCON. Falco gyrfalco candicans.

Rare winter visitor. Breeds in the Aretic Regions of Lastern America and Greenland, wandering irregularly southwards in winter.

\section{PEREGRINE FALCON. Falco peregrinus.}

Resident in the wildest parts of the three lingdoms; numbers increased in spring and autumn by migrants. Circumpolar species, migrating southwards in autumn from the coldest parts of its range.

H0BBY. Falco subbuteo.

Very local summer visitor to England; rare spring and autumn migrant in Scotland and Ireland. Breeds in Europe and Siberia south of the Aretic Circle. Winters in South Africa, North India, and South China.

\section{JUGGER FALCON. Falco jugger.}

Supposed accidental visitor; only one British record (Flamborongh), probably of an escaped bird. Resident in India. 



\section{MERLIN. Falco æsalon.}

Partial resident, breeding on the moor's. Breeds in North Europe and North Siberia. Winters in South Europe, North Africa, North-west India, and South China.

\section{RED-F00TED FALCON. Falco vespertinus.}

Accidental visitor to England, a score or more examples; very rare in Scotland and Ireland. Brecds in Eastern kurope and Western Siberia south of the Aretic Circle. Winters in South Africa.

\section{KESTREL. Falco tinnunculus.}

Common resident. Breeds in North Ifrica, Europe, and Asia, in Scandinavia as far north as the Arctic Circle, in Siberia to about lat. $58^{\circ}$. Migrates south in autumm from the aretic part of its range to winter in the tropics, where the resident birds constitute tropical races.

LESSER KESTREL. Falco cenchris.

Accidental visitor; four British records (Yorkshire, Kent, Dublin, Scilly Isles). Breeds in the basin of the Mediterranean, Persia, and Russian Turkestan. Winters in South Africa.

\section{AMERICAN KESTREL. Falco sparverius:}

Supposed accidental visitor; only one British record (Yorkshire). Breeds in aretic and subaretic North America; resident in temperate North America and a winter visitor to the tropical parts of that continent.

\section{SWALLOW-TAILED KITE. Elanoides furcatus.}

Supposed accidental visitor; only two British records (Argyleshire, Yorkshire). Breeds in the Southern States of North America east of the Rocky Mountains, Winters in tropical America. 



\section{HONEY-BUZZARD. Pernis apivorus.}

Spring and autumn migrant; occasionally breeding in England and Scotland. Summer visitor to Europe south of the Aretic Circle and north of lat. $45^{\circ}$, Southern Siberia, North China, and Japan. Winter visitor to tropical Africa, India, and Burma.

\section{COMMON KITE. Milvus regalis.}

Accidental visitor to England and Ireland; a few still breeding in Wales and Scotland. Summer visitor to North Europe south of lat. $60^{\circ}$. Resident in the Canaries, North-west A frica, and Central and Southern Europe as far east as the valley of the Don.

\section{BLACK KITE. Milvus ater.}

Accidental visitor; one British recorl (Northumberland). Breeds in North-west Africa, Europe south of the Baltic, Palestine, Asia Minor, Persia, and Russian Turkestan. Winters in South Africa. Has all:es in Asia, Australia, and Africa, from which it is doubtful if it be specifically distinet.

\section{WHITE-TAILED EAGLE. Haliaetus albicilla.}

Rare winter visitor to England; local resident in Scotland and Ireland. Breeds in Europe and Siberia south of the Arctic Circle, North Africa, Asia Minor, Persia, Turkestan, and South China. Migrates south from the coldest parts of its range.

\section{GOLDEN EAGLE. Aquila chrysaetus.}

Rare winter visitor to England; local resident in Scotland and Ireland. Circumpolar species, breeding in the mountainous districts of the northerm hemisphere from the confines of the Aretic Region to the borders of the 'Tropics. 

LESSER SPOTTED EAGLE. Aquila nævia.

Accidental visitor; six English and one Irish record. Breeds in Central Europe as far north as Pomerania, as far west as Hanover, and as far south and east as the Caucasus. Has allies in South Europe and Asia, from which it is doubtful if it be specifically distinct.

\section{ROUGH-LEGGED BUZZARD-EAGLE. Archibuteo lagopus.}

Rare winter visitor. Breeds in Aretic Europe and Siberia as far east as the Yenesei. Wander's in winter to Central and Southern Europe and Russian Turkestan.

\section{COMMON BUZZARD. Buteo vulgaris.}

Rare resident. Resident in Europe up to lat. $66^{\circ}$ in the west, to $59^{\circ}$ in the east. Has several close allies in Asia, from which it is doubtful if it be specifically distinct.

\section{MARSH-HARRIER. Circus æruginosus.}

Accidental visitor, formerly resident, still locally so in Ireland. Summer visitor to Central Europe, Turkestan, and South Siberia. Resident in South Europe, North Africa, Persia, North China, and Japan. Winter visitor to Central Africa, India, Ceylon, and South China. Eastern examples generally differ from western ones.

\section{HEN-HARRIER. Circus cyaneus.}

Rare winter visitor, occasionally remaining to breed. Summer risitor to arctic and subaretic Europe and Asia, migrating in winter to the confines of the Tropics, in Africa as far south as Abyssinia.

\section{MONTAGU'S HARRIER. Circus cineraceus.}

Rare summer visitor, occasionally allowed to breed; very rare in Scotland and Ireland. Breeds in Central and Southern Lurope, Russian 'Turkestan, and South Siberia as far' east as the Yenesei. Winters in Central and Southern Africa, India, Ceylon, and Burma. 



\section{SPARROW-HAWK. Accipiter nisus.}

Resident. Breeds asross Europe and Asia south of the Arctic Circle (in Norway to lat. $69^{\circ}$ ), wintering in the basin of the Mediterranean, India (where a few breed in the Himalayas), Burma, China, and Japan.

\section{G0SHAWK. Accipiter palumbarius.}

Rare winter visitor; formerly breeding in Scotland, accidental in Ireland. Breeds across Europe and Asia nearly as far north as the limit of forest-growth; wintering in the Tropics.

\section{AMERICAN GOSHAWK. Accipiter atricapillus,}

Accidental visitor; three British records (two Irish, one Scotch). Brects across Arctic America and the Northern States, migrating southwards in autumn from the extreme north of its range.

\section{Family PANDIONIDÆ.}

\section{OSPREY. Pandion haliaetus.}

Spring and autumn migrant; very rare in Ireland, a few breeding in Scotland. Breeds across Europe, Asia, and America nearly as far north as the limit of forest-growth. Resident in the subtropical parts of those continents, and winter visitor to the Tropics.

\section{Suborder HERODIONES.}

\section{Family ARDEIDÆE.}

\section{COMMON HERON. Ardea cinerea.}

Resident. Summer visitor to Europe south of lat. $65^{\circ}$ and temperate Asia south of $55^{\circ}$. Resident in most parts of Africa and tropical Asia. Winter visitor to Java and Australia.

\section{PURPLE HERON. Ardea purpurea.}

Accidental visitor; about fifty records (only two Scotch and only one Irish). Resident in most parts of Africa, Sicily, Palestine, Persia, 'Turkestan, India, Ceylon, and Burma. Summer visitor' to Central and Southern Europe and China. Winter visitor to the Malay Archipelago. 

GREAT WHITE EGRET. Ardea alba.

Accidental visitor; eight or ten English and Scotch occurrences. Resident in Africa, India, Ceylon, Burma, and China. Summer visitor to South-east Europe, Asia Minor, Palestine, Persia, Turkestan, South Siberia, and Japan. Eastern examples are smaller than western ones.

\section{LITTLE EGRET. Ardea garzetta.}

Accidental visitor; half a dozen records (English and Scotch). Resident in most parts of Africa, India, Ceylon, Burma, South China, and South Japan. Summer risitor to South Europe, Palestine, Asia Minor, and North China. Winter visitor to the Malay Archipelago and North Australia.

\section{SQUACCO HERON. Ardea comata.}

Accidental visitor; about forty records, including half a dozen Irish and two Scotch. Resident in most parts of Africa. Summer visitor to South Europe and Persia.

\section{BUFF-BACKED HERON. Ardea bubulcus.}

Accidental visitor; two or three English records. Resident in most parts of Africa, the south of the Spanish Peninsula, and Palestine. Most Spanish birds migrate south in autumn.

GREEN HER0N. Ardea virescens.

Accidental visitor; only oue British record (Cornwall). Summer visitor to South Canada and the Northern States. Resident in tropical North America.

\section{NIGHT-HERON: Ardea nycticorax.}

Rare summer visitor, but never allowed to breed. Resident in the Tropics, and summer visitor to the subtropical parts of Europe, Asia, Africa, and America. 

COMMON BITTERN. Botaurus stellaris.

Very rare resident. Resident in most parts of Africa, and in Palestine and Asia Minor. Summer visitor to Europe and Siberia south of lat. $60^{\circ}$, Persia, Turkestan, North China, and Japan. Winter visitor to India and Burma.

\section{AMERICAN BITTERN. Botaurus lentiginosus.}

Aceidental visitor ; a score British records. Summer visitor to Canada south of lat. $60^{\circ}$ and the Northern States. Resident in the Southern States. Winter visitor to the West Indies and Central America.

\section{LITTLE BITTERN. Botaurus minutus.}

Rare summer risitor. Breeds in Europe south of the Baltic, Palestine, Asia Ninor, Persia, Russian Turkestan, and the Western Himalayas. Resident in the Azores, Madeira, and North Africa. Winter visitor to South Africa and North-west India.

\section{Family CICONIID E.}

WHITE STORK. Ciconia alba.

Aceidental risitor. Summer visitor to Algeria, Europe south of lat. 60", Palestine, Asia Minor, Persia, and Turkestan as far east as Yarkand. Winter visitor to Africa south of the Desert and North India.

BLACK STORK. Ciconia nigra.

Accidental visitor to England; a dozen records. Summer visitor to Europe and Siberia south of lat. 55 , Persia, and 'l'urkestan. Winter visitor to Africa, Northern and Central India, and Central China. 



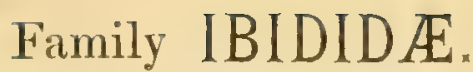

GLOSSY IBIS. Ibis falcinellus.

Accidental visitor, formerly more common. Summer visitor to North Africa, South Europe, Russian Turkestan, and South-west Siberia. Resident in Sind and Ceylon. Winter visitor to Africa, the Malay A rehipelago, and Australia.

\section{SP00NBILL. Platalea leucorodia.}

Accidental visitor, a few breeding colonies in England still remaining in the 17th century. Summer visitor to Europe and Siberia south of lat. 50 . Resident in North Africa, India, Ceylon, North China, and Japan.

\section{suborder STEGANOPODES.}

\section{Family SULID E.}

GANNET. Sula bassana.

Common resident, but confined to about half a dozen breeding colonies. Breeds also on rocky islands off the Canadian coast, Iccland, and the Faroes, wandering in winter to the confines of the Tropics.

\section{Family PHALACROCORACIDÆ.}

\section{CORMORANT. Phalacrocorax carbo.}

Common resident. Summer visitor to Greenland and South Siberia. Resident on the east coast of Canadi, Algeria, inland across Europe, North India, Burma, the Malay Arehipelago, Australia, Tasmania, and New Zealand. Winter visitor to the coasts of tropical Africa and India.

\section{SHAG. Phalacrocorax graculus.}

Common resident on our rocky coasts. Breeds on the rocky coasts of Iceland, Norway, France, Spain, Portugal, and on the rocky shores of the Mediterranean. Does not wander far in winter. 



\section{Order A LCIFORMES.}

\section{Suborder TUBINARES.}

\section{Family PROCELLARIIDÆ.}

STORMY PETREL. Procellaria pelagica.

Resident on rocky islands off various parts of the British coast. Breeds on islands in the North Atlantic, migrating in winter from the northern parts of its range to the coasts of West and South Africa.

\section{LEACH'S PETREL. Procellaria leachi.}

Occasional visitor to all our coasts, breeding on a few of the Westem Islands of Scotland and Ireland. Resident in the North Atlantic and North Pacific Oceans, breeding on islands.

\section{WILSON'S PETREL. Oceanites wilsoni.}

Occasional visitor to the coasts of England and Ireland. Breeds in December on Kerguclen Island, and probably on other islands in the southern hemisphere, wandering after the breeding-scason to the oceans of the northern hemisphere.

\section{Family PUFFINIDÆ.}

MANX SHEARWATER. Puffinus anglorum.

Common resident, breeding on various islands off the coasts of Ireland and the west of Scotland and England. Atlantic and Mediterranean specics brecding from Iceland to the Azores. In winter occasionally found on the American coast.

\section{GREAT SHEARWATER. Puffinus major.}

Frequent but irregular visitor to all our coasts. Breeding-grounds nnknown. Is common in the Atlantic, and has once occurred in the South Pacific. 



\section{DUSKY SHEARWATER. Puffinus obscurus.}

Accidental visitor; two British records (Suffolk and Kerry). Circum. tropical species, breeding as far north as Madeira.

\section{SOOTY SHEARWATER. Puffinus griseus.}

Occasional autumn migrant to all our coasts. Oceanic species, breeding on the Chatham Islands near New Zealand, and doubtless on many other islands in the southern hemisphere. Winters (during our summer) in the northern hemisphere.

\section{CAPPED PETREL. Estrelata hæsitata.}

Accidental visitor; only one British record (Norfolk). Supposed to breed in the West Indies.

\section{MACGILLIVRAY'S PETREL. Estrelata torquata.}

Accidental visitor; only one British record (Cardigan Bay). Breeds on some of the New Ilebrides, and probably on other islands in the southern seas.

\section{BULWER'S PETREL. Bulweria columbina.}

Accidental visitor; only one authentic British record (Yorkshire). Circumtropical species, breeding as far north as Madeira.

\section{FULMAR. Fulmarus glacialis.}

Breeds in enormous numbers on St. Kilda, and very sparingly on one or two other of the Western Isles; rare visitor to the rest of our coasts. Circumpolar species, seldom, if ever, straying as far south as the Tropics.

\section{CAPE PETREL. Daption capense.}

Accidental visitor; only onc British record (Dublin). Frequents all the southern scas, and is said to breed on the island of South Georgia. Egg unknowu. 



\section{Suborder ALC压.}

\section{Family ALCIDÆ.}

\section{RAZ0RBILL. Alca torda.}

Common resident. North Atlantic species, breeding from Nova Scotia, Greenland, and Iceland to Seandinavia, the British Islands, and North France. Migrates in autumn from the coldest parts of its range as far as the confines of the Tropics.

\section{LITTLE AUK. Alca alle.}

Irregular winter visitor. North Atlantic species, breeding north of the Aretic Circle from the north of Baffin's Bay to Grimsey Island, FranzJosef Land, and Nova Zembla. Wanders southwards in winter, but not so far as the Tropics.

\section{BLACK GUILLEM0T. Alca grylle.}

Resident on the Irish coasts and the west coast of Scotland; rare winter visitor to England. Subarctic Atlantic species, resident from Newfoundland and Iceland to the White Sea.

\section{COMMON GUILLEMOT. Alca troile.}

Resident. Circumpolar species, divisible into several local races. Typical form breeds in the North Atlantic from Nova Scotia, South Greenland, South Iceland, and Bear Island to the coasts of Norway, the British Islands, and West Europe.

\section{BRÜNNICH'S GUILLEMOT. Alca troile bruennichi.}

Accidental visitor; two British records (Orkneys, Suffolk). Arctic race of Common Guillemot, breeding from Labrador, Baffin's Bay, North Iceland, Jan Mayen, and Spitzbergen to Franz-Josef Land and Nova Zembla. Occasionally strays southwards in winter.

\section{GREAT AUK. Alcá impennis.}

Accidental winter visitor, which became extinct nearly half a century ago. North Atlantic species, formerly breeding on islands off the coasts of Newfoundlaud, Labrador, South Greenland, Iceland, and Norway. 

PUFFIN. Fratercula arctica.

Common summer visitor, a few remaining to winter. North Atlantic species, breeding from Baffin's Bay and Iceland to the British Islands, Norway, Spitzbergen, and Nova Zembla. Aretic examples have very large bills.

\section{Order GALLIFORIMES.}

\section{Suborder GALLIN㞋.}

\section{Family PHASIANIDÆ.}

COLCHICAN PHEASANT. Phasianus colchicus.

Naturalized resident ; introduced many centuries ago. Resident in Asia Ninor, South-cast Russia, and North-west Persia. Introduced into most countries of Europe.

CHINESE RINGED PHEASANT. Phasianus torquatus.

Naturalized resident; interbrecding frecly with the Colchican Phicasint; introduced about a ccutury ago. Resident in South-cast Siberia and East China.

COMMON PARTRIDGE. Perdix cinerea.

Resident in Central and Southern Europe, Asia Minor, North Persia, and South-west Siberia. From the latter locality many migrate to winter in North Turkestan.

RED-LEGGED PARTRIDGE. Perdix rufa,

Naturalized resident in South-east England; introduced about a century ago. Resident in West Europe, Madeira, and the Azores.

\section{QUAIL. Coturnix communis.}

Summer visitor; a few wintering in Ireland and the south of England. Summer visitor to North Europe and South Sibcria. Partial resident in South Europe and North Africa. Winter visitor to South Africa and South Asia. 

CAPERCAILLIE. Tetrao urogallus.

Resident, indigenous up to the middle of last century ; re-introduced in Central Scotland half a century ago. Resident in the pine-forcsts of the Pyrenees, Alps, Carpathians, the north of Europe, and the south of Siberia as far north as the Aretic Circle, and as far cast as Lake Baikal.

\section{BLACK GROUSE. Tetrao tetrix.}

Resident in Scotland, England, and Wales. Resident in most pineforests of Central Europe, North Russia, North-east Turkestan, and South Siberia as far east as the Ussuri River.

\section{RED GROUSE. Tetrao scoticus.}

Resident on most large heath moor's in the three kingdoms except in the south-east of England. Not found outside the British Islands.

\section{PTARMIGAN. T'etrao mutus.}

Resident in the II ighlands of Scotland. Circumpolar species, divisible into several local races. The typical race is a resident on most of the mountain ranges of Europe which, either by latitude or eleration, reach an arctic climate.

\section{Suborder PYGOPODES. Family COLYMBIDÆ.}

\section{GREAT NORTHERN DIVER. Colymbus glacialis.}

Common winter visitor; said to have bred in the Shetland Islands. Brecds in aretic America and Iceland, wandering southwards in winter to the confines of the 'Tropics.

\section{WHITE-BILLED DIVER. Colymbus adamsi.}

Rare winier visitor; four British records (Northumberland, Norfoll, and Suffolk). Circumpolar species, wandering in winter as far south as the coasts of Britain and Japan. 

BLACK-THROATED DIVER. Colymbus arcticus.

Breeds in the north and west of Scotland; rare winter visitor to England and Ireland. Circumpolar species, breeding in the Arctic Regions, wintering in the temperate parts of the northern hemisphere.

\section{RED-THROATED DIVER. Colymbus septentrionalis.}

Breeds in the north and west of Scotland and in the north of Ireland; winter visitor to the coasts of England and Ireland. Circumpolar species, breeding in the Arctic Regions, wandering in winter to the frontiers of the Tropics.

\section{Family PODICIPIDÆ.}

GREAT CRESTED GREBE. Podiceps cristatus.

Local resident. Resident in all parts of the Old World, including New Zealand, except in the Aretic Regions and the 'Tropics. Summer visitor' only where the winters are severe.

\section{RED-NECKED GREBE. Podiceps rubricollis.}

Winter visitor. Circumpolar species, breeding in the subaretic and temperate parts of Europe, Asia, and North America. Summer visitor only where the winters are severe. East Asian and American cxamples are slightly larger than the typical form.

\section{EARED GREBE. Podiceps nigricollis.}

Rare spring and autumu migrant; said to have bred in Norfolk. Resident in the basin of the Mediterranean and South Africa. Summer visitor to Central Europe and South Siberia, wintering on the coasts of Baluchistan and China. A race only subspecifically distinct is a resident in the Western States, Mexico, and Central America.

\section{SCLAVONIAN GREBE. Podiceps cornutus.}

Winter visitor; a few supposed to breed in the north of Scotland. Circumpolar species, arctic in Norway, subaretic in the rest of its range. Wanders in winter as far south as the frontiers of the Tropics.

\section{LITTLE GREBE. Podiceps minor.}

Common resident. Summer visitor to Central Europe. Resident in South Europe, Africa, and South Asia. 



\section{Suborder LIMICOL伥.}

\section{Family CHARADRIIDÆ.}

\section{GREY PLOVER. Charadrius helveticus.}

Common spring and autumn migrant. Circumpolar species, brecding in the Arctic Regions. Winters in the basin of the Mediterranean, South Africa, India, South China, the Malay Archipelago, Australia, tho Pacific Islands, South America, and the West Indies.

\section{GOLDEN PLOVER. Charadrius pluvialis.}

Common winter visitor, a few remaining to breed on the moors. Breeds in North Europe and West Siberia. Winter's in South Europe, Africa, and Baluchistan.

\section{ASIATIC GOLDEN PLOVER. Charadrius fulvus.}

Accidental visitor; two British records (Norfolk and Orkneys). Breeds in North-east Siberia. Winters in India, Burma, China, the Malay Archipelago, Australia, and the Pacific Islands, including New Zealand.

\section{AMERICAN GOLDEN PLOVER. Charadrius fulvus americanus.}

Accidental visitor; two British records (England and Scotland). Breeds in arctic America from Alaska to Greenland. Winters in South America. Intergrades with the Asiatic Golden Plover in East Siberia.

\section{DOTTEREL. Charadrius morinellus.}

Frequent spring and autumn migrant, a few remaining to breed on the wildest moors. Summer visitor to aretic Europe and Siberia, wintering in the basin of the Mediterranean.

\section{KILLDEER PLOVER. Charadrius vociferus.}

Accidental visitor; two British records (south of England). Summer visitor to South Canada and the Northern States. liesident in the Southern States. Winter visitor to Mexico, West Indies, and South America. 

RINGED PLOVER, Charadrius hiaticula.

Frequent spring and autumn migrant. Breeds in Greenland, Europe north of the Alps, and West Siberia. Winters in Southern Europe and Africa.

BRITISH RINGED PLOVER. Charadrius hiaticula major.

A large race of the Common Ringed Plover, resident in the British Islands, Holland, and North France. Intergrades with the Continental form.

\section{LITTLE RINGED PLOVER. Charadrius minor.}

Accidental visitor to England; half a dozen records. Breeds in South Europe and South Siberia, migrating in autumm from the coldest parts of its breeding-range to winter in tropical Africa, India, Burma, and the Malay Archipelago.

\section{CASPIAN PLOVER. Charadrius asiaticus.}

Accidental visitor; only one British record (Norfolk). Breeds in the basins of the Caspian and Aral Seas. Winters in Africa, south of the Sahara.

KENTISH PLOVER. Charadrius cantianus.

Rare spring and autumn migrant, a few remaining to breed in the south-east of England. Brecds on inland seas and salt lakes from Holland to Mongolia, migrating in autumu from the northern parts of its breedingrange to winter on the coasts of Africa and Southern Asia.

\section{LAPWING. Vanellus cristatus.}

Common resident. Summer visitor to subaretic Europe and South Siberia. Resident in temperate Europe and Asia. Winter visitor to the basin of the Mediterranean, Asia Minor, Persia, North India, China, and South Japan.

SOCIABLE LAPWING. Vanellus gregarius.

Accidental visitor; only one British record (Lancashire). Breeds in South-east Russia and South-west Siheria. Winters in North-east Africa and India. 

OYSTER-CATCHER. Hæmatopus ostralegus.

Commou resident. Breeds on all the coasts of Europe, and on the rivers and lakes of West Siberia and Turkestan. Winters on the coast of West and North Africa, and on the shores of the Arabian Sea.

\section{COMMON STILT. Himantopus candidus.}

Accidental visitor; forty or fifty British records. Summer visitor to the basin of the Mediterranean, South Russia, Asia Minor, Persia, Turkestan, and Afghanistan. Resident in India and Ceylon. Winter visitor to Africa, Burma, and occasionally further east.

\section{AVOCET. Himantopus avocetta.}

Rare spring and autumn migrant; bred in the Eastern Counties seventy years ago. Summer visitor to South Europe, Denmark, IIolland, Persia, Turkestan, and South Siberia. Resident in many parts of Africa. Winter visitor to India, Ceylon, and China.

\section{COMMON CURLEW. Numenius arquata.}

Resident; numbers increased in winter. Breeds in temperate Europe and South Sibcria. Winters on the coasts of Africa and South Asia. Eastern examples generally differ slightly from the typical form.

\section{COMMON WHIMBREL. Numenius phæopus.}

Common spring and autumn migrant, a few remaining to breed in the north of Scotland. Breeds in arctic Europe and Siberia. Winters on the coasts of tropical Africa, North Asia, Australia, and many of the Pacific Islands. Eastern examples vary slightly from western ones.

ESQUIMO WHIMBREL. Numenius borealis.

Accidental visitor; half a dozen British records. Brecds in arctic America. Winters in South America, south of the Equator.

\section{GREY PHALAROPE. Phalaropus fulicarius.}

Irregular winter visitor. Circumpolar species, breeding in the Aretic Regions. Winters irregularly further south, very rarcly wandering as far as the Equator. 

RED-NECKED PHALAROPE. Phalaropus hyperboreus.

Rare spring and autumn migrant, a few remaining to breed on the Western Islands; has only once occurred in Ireland. Circumpolar species, breeding in the Arctic Regions. Winters in North Africa, South Asia, Mexico, and Central America.

\section{DUSKY REDSHANK. Totanus fuscus.}

Rather rare spring and autumn migrant. Breeds in arctic Europe and Asia. Winters in South Europe, North Africa, and South Asia.

\section{GREENSHANK. Totanus glottis.}

Common spring and autumn migrant, a few remaining to breed on the Scotch moors. Breeds in Europe and Asia near the Arctic Circle. Winters in South Europe, Africa, South Asia, and Australia.

\section{REDSHANK. Totanus calidris.}

Common resident. Breeds in subarctic and temperate Europe and Asia, migrating from the coldest parts of its breeding-range to winter in Africa and South Asia.

\section{GREEN SANDPIPER. Totaneus ochropus.}

Rare spring and autumn migrant. Breeds in subarctic Europe and Asia. Winters in South Europe, Africa, and South Asia.

\section{SOLITARY SANDPIPER. Totanus solitarius.}

Accidental visitor; has occurred twice in England and probably once in Scotland. Breeds in subarctic North America. Winters in tropical South America.

\section{WO0D-SANDPIPER. Totanus glareola.}

Rare spring and autumn migrant. Breeds in arctic and subarctic Europe and Asia. Winters in the basin of the Mediterranean, Africa, Persia, India, Burma, and the Malay Archipelago. 

SIBERIAN PECTORAL SANDPIPER. I'ringa acuminata.

Accidental visitor; two British records (Norfolk). Summer visitor to East Siberia; winter visitor to Australia and some of the Pacific Islands.

\section{YELLOWSHANK. Totanus flavipes.}

Accidental visitor; two British records (Nottinghamshire and Cornwall). Breeds in aretic America and winters in South America.

\section{BARTRAM'S SANDPIPER. Totanus bartrami.}

Accidental visitor; half a dozen English records. Breeds in South Canada and the Northern States. Winters in tropical and subtropical America.

\section{COMMON SANDPIPER. Totanus hypoleucus.}

Common summer visitor. Breeds in temperate Furope and Asia. Winters throughout Africa and in tropical Asia, New Guinea, and North Australia.

\section{SPOTTED SANDPIPER. Totanus macularius.}

Accidental visitor; half a dozen English and Scotch records. Breeds in South Canada and in the States. Winters in Mexico and tropical America.

\section{RUFF. Totanus pugnax.}

Rather rare spring and autumn migrant, occasionally remaining to breed in the Norfolk marshes. Breeds in Northern Europe and Siberia. Winters in Africa, Northern India, Burma, and Japan.

\section{TURNSTONE. Strepsilas interpres.}

Frequent spring and autumn migrant, a few remaining to winter. Circumpolar species, breeding in the Arctic and Subarctic Regions. Winters in nearly all tropical and subtropical parts of the world.

KN0T. Tringa canutus.

Common winter visitor. Breeds in the extreme Arctic Regions of America. Winters on all tropical and temperate coasts throughout the world. 



\section{CURLEW SANDPIPER. Tringa subarquata,}

lirequent spring and antumu migrant. Breeds in some unknown part of the Arctic Regions; seen on migration from Lapland to Bering Strait. Winters in Africa, South Asia, and Australia.

BONAPARTE'S SANDPIPER. Tringa bonapartii.

Accidental visitor; a dozen English and one Irish record. Breeds in arctic America cast of the Rocky Mountains. Winters in the West Indies, Central America, and South America.

\section{DUNLIN. Tringa alpina.}

Common winter visitor, a few remaining to breed on the moors. Circumpolar species, breeding in the Arctic and Subarctic Regions. Winters on most tropical and subtropical coasts.

\section{PURPLE SANDPIPER. Tringa maritima.}

Frequent winter visitor. Circumpolar species, breeding in the Arctic Regions. Winters in the north temperate regions of both hemispheres.

\section{SANDERLING. Tringa arenaria.}

Common spring and autumn migrant, a few remaining to winter. Circumpolar species, breeding in the Arctic Regions. Winters in nearly every tropical and subtropical region.

\section{TEMMINCK'S STINT. Tringa temmincki.}

Rare spring and autumn migrant. Breeds in arctic Europe and Siberia. Winters in the basin of the Mediterranean, North Africa, India, Ceylon, Burma, South China, and the Malay Archipelago.

\section{BUFF-BREASTED SANDPIPER. Tringa rufescens.}

Accidental visitor; a dozen British records. Breeds in arctic America. Winters in Mexico, the West Indies, Central America, and tropical South America. 

PECTORAL SANDPIPER. Tringa pectoralis.

Accidental visitor; a score British records. Breeds in arctic America. Winters in most parts of the Neotropical Region.

\section{LITTLE STINT. Tringa minuta.}

Frequent spring and autumn migrant. Breeds in arctic Europe and North-west Siberia, from Lapland to the valley of the Yenisei. Winters in Africa, Persia, India, and Ceylon.

\section{AMERICAN STINT. Tringa minutilla.}

Accidental visitor; only two British records (Cornwall and Devonshire). Breels in aretic America. Winters in the Southern States, Mexico, the West Indies, Central America, and tropical South America.

\section{BROAD-BILLED SANDPIPER. Tringa platyrhyncha.}

Rare spring and autumn migrant to Englaud and Ireland; only six or seven British records. Breeds in aretic Europe and Siberia. Winters in the basin of the Mediterranean, North Africa, and South Asia.

\section{BLACK-TAILED GODWIT. Limosa melanura.}

Rare spring and autumm migrant; bred on the Norfolk marshes sixty years ago. Breeds in Central Europe, Turkestan, and South Siberia. Winters in the basin of the Mediterranean, South Asia, the Malay Archipelago, and North Australia. Eastern examples arc, on an average, smaller than western ones.

\section{BAR-TAILED GODWIT. Limosa rufa.}

Common spring and autumn migrant. Breeds in arctic Europe and Siberia. Winters on the shores of the Mediterranean and Arabian Seas, and in the Malay Archipelago, Australia, and the Pacific Islands, including New Zealand. Eastern examples generally differ slightly from western ones.

\section{AMERICAN SNIPE-BILLED SANDPIPER. Macrorhamphus griseus.}

Accidental visitor to England and Scotland; more than a dozen records. Brecds in aretic America. Winters in subtropical North America and tropical South America. Eastern examples differ slightly from western ones. 

W00DCOCK. Scolopax rusticola.

Common winter visitor, a few remaining to breed. Breeds in the sub. arctic climates of Europe and Asia, from the Azores to Japan. Winter's in the basin of the Mediterranean, Persia, India, Burma, and China.

\section{GREAT SNIPE. Scolopax major.}

Rare spring and autumn migrant. Breeds in the Subarctic Regions of Europe and Western Asia from Scandinavia to the valley of the Yenisei. Winters in South Africa, and in small numbers in the basin of the Mediterranean.

\section{COMMON SNIPE. Scolopax gallinago.}

Common resident on swampy ground. Breeds in North Europe and Siberia, and at high elevations further sonth. Winters in South Europe, North Africa, and South Asia.

\section{JACK SNIPE. Scolopax gallinula.}

Common winter visitor. Breeds in arctic Lurope and Siberia. Winters in South Europe, North Africa, and South Asia.

\section{Suborder GAVIÆE.}

\section{Family EDICNEMID艮.}

\section{STONE-CURLEW. Edicnemus crepitans.}

Breeds locally in England, occasionally wintering in the south; accidental visitor to Scotland and Ireland. Breeds in Central and Southern Europe, North Africa, and South-west Asia, migrating southwards in autumn from the coldest parts of its breeding-range.

\section{Family CURSORIIDÆ.}

CREAM-COLOURED COURSER. Cursorius gallicus.

Acciủental visitor; a score English and one Scotch record. Brecds in the Canary Islands, North Africa, Arabia, Persia, and West Turkestan.

COMMON PRATINCOLE. Glareola pratincola.

Accidental visitor; a score British records. Breeds across Southern Europe and Asia Minor as far east as Russian 'Turkestan. Winters iu Central and Southern Africa. 



\section{Family LARID $\mathbb{E}$.}

\section{COMMON NODDY. Anous stolidus.}

Accidental visitor; only one British record (two examples shot together in Ireland). Circumtropical species, breeding on many tropical islands in both hemispheres.

\section{BLACK TERN. Sterna nigra.}

Rare spring and autumn migrant; bred in the Eastern Counties thirty years ago. Breeds in Central and South Europe and Turkestan. Winters in North Africa. Represented in America by a form only subspecifically distinct.

\section{WHITE-WINGED BLACK TERN. Sterna leucoptera.}

Accidental visitor; a score English and four Irish records. Breeds from the basin of the Mediterranean eastwards to South Sibcria arid North China. Winters in tropical Africa and South Asia.

\section{WHISKERED TERN. Sterna hybrida.}

Accidental visitor; only four English records and one Irish. Breeds in South Europe, North Africa, Turkestan, North India, and South Mongolia. Winters in tropical Africa and South Asia. A tropical form said to be indistinguishable in summer plumage breeds in North-east Australia.

\section{SOOTY TERN. Sterna fuliginosa.}

Accidental visitor; only three British records, all English. Circumtropical species, breeding on many tropical islands in both hemispheres.

\section{BRIDLED TERN. Sterna anæstheta.}

Accidental visitor; only one British record (Thames estuary). Circumtropical species, breeding on many tropical islands in both hemispheres. 

CASPIAN TERN. Sterna caspia.

Rare spring and autumn migrant to the cast coast of England; less than a score authentic records. Circumtropical species; summer visitor to the coasts of Denmark and South Europe. Resident on the coasts of tropical Africa, South Asia, Australia, and New Zealand. Summer visitor to subarctic North America, wintering in subtropical North America.

\section{SANDWICH TERN. Sterna cantiaca.}

Summer visitor, breeding very locally in some numbers. Breeds on the coasts of Denmark, and the shores of the Mediterranean, Black, and Caspian Seas. Winters on the west and north coasts of Afriea, and the shores of the Arabian Sea. In America breeds on the coasts of the Atlantic States, wintering on the Atlantic coast of tropical South America.

\section{GULL-BILLED TERN. Sterna anglica.}

Rare spring and autumn migrant; a score English and one Irish record. Sumıner visitor to Denmark, South Europe, Turkestan, Cashmere, and South Mongolia. Winters and is locally resident in North Africa and tropical Asia. In North America breeds on the temperate and tropical shores of the Atlantic; winters on the east coast of South America.

\section{COMMON TERN. Sterna hirundo.}

Common summer visitor to many parts of the coast. Breeds in the temperate region of the northern hemisphere from the Azores west to the Great Bear Lake, and east to the Caspian Sea. Winters on the tropical shores of the Atlantic Ocean and the Arabian Sea.

\section{ARCTIC TERN. Sterna arctica.}

Common summer visitor to many parts of the cuast. Circumpolar species, breeding in the Arctic and Subarctic Regious of both hemispheres. Winters on the tropical and subtropical shores of the Atlantic.

\section{ROSEATE TERN. Sterna dougalli.}

Rare summer visitor; bred in a few localities lialf a century ago. Circumtropical species resident on the coasts of many tropical islands. 



\section{LITTLE TERN. Sterna minuta.}

Summer visitor to a few scattered breeding-stations on our coasts. Breeds in South Europe, Asia Minor, Persia, and Turkestan. Winters in West Africa and the valley of the Nile.

\section{ROSS'S GULL. Larus rossi.}

Accidental visitor; only one British record (Yorkshire). Circumpolar species, breeding in the extreme north, and not wandering far south in winter.

\section{SABINE'S GULL. Larus sabini.}

Rare winter visitor. Circumpolar species, breeding in the extreme north, wandering irregularly south in winter, but rarely visiting the southern hemisphere.

\section{LITTLE GULL. Larus minutus.}

Rare winter visitor. Breeds in subarctic Russia and Siberia. Winters on the coasts of Southern Europe and Northern Africa.

\section{BONAPARTE'S GULL. Larus philadelphia.}

Accidental visitor; half a dozen British records. Breeds in subarctic North America. Winters on the Californian coast and on the shores of the Gulf of Mexico.

\section{BLACK-HEADED GULL. Larus ridibundus.}

Common resident, breeding on a few favoured swamps, wintering on the coast. Breeds across Central Europe, Turkestan, and South Siberia. Winters on the shores of the Mediterranean and Red Seas, and on the coasts of North India, China, and Japan.

ADRIATIC BLACK-HEADED GULL. Larus melanocephalus.

Accidental visitor; only two British records, both English. Resident in the basins of the Mediterranean and Black Seas 

GREAT BLACK-HEADED GULL. Larus ichthyaetus.

Accidental visitor; only one British record (Devonshire). Central Asian species, breeding from the Caspian Sea to Mongolia. Winters in the valley of the Nile, and eastwards in South Asia as far as Assam.

GREAT BLACK-BACKED GULL. Larus marinus.

Resident, but very local. Circumpolar species, breeding in the Arctic and Subarctic Regions of Europe, Asia, and America. Winters north of the 'Tropics.

\section{LESSER BLACK-BACKED GULL. Larus fuscus.}

Common resident on our rocky coasts. Breeds on the west and south coasts of Europe from Norway to the Black Sea. Migrates from the colder part of its breeding-range to winter on the coast of West Africa.

\section{HERRING-GULL. Larus argentatus.}

Common resident on our rocky coasts. North Atlantic species, breeding in subaretic America as far west as Great Slave Lake, and in subarctic Lurope as far east as Norway. Winters in North America from the States to Guatemala, and in Europe as far south as Spain.

\section{GLAUCOUS GULL. Larus glaucus.}

Irregular winter visitor. Circumpolar species, breeding on islands in the Arctic Ocean, and in very high latitudes on the coasts of both continents. Winters north of the Tropics.

\section{ICELAND GULL. Larus leucopterūs.}

Irregular winter visitor. Breeds in high latitudes in arctic America from Alaska to Greenland. Seldom wanders far into the temperate regions in winter.

\section{COMMON GULL. Larus canus.}

Common resident in Scotland, rarer in Ireland, winter visitor to England. Breeds in subarctic Lurope and Asia. Winters on the shores of the Mediterranean, Black, and Caspian Seas, and on the coasts of China and Japan. 



\section{KITTIWAKE GULL. Larus tridactylus.}

Conmon resident on our rocky coasts. Circumpolar species, breeding in the Arctic and Subarctic Regions, rarely wandering southwards as far as the Tropics in winter.

\section{IV0RY GULL. Larus eburneus.}

Rare winter visitor; thirty to forty British records. Circumpolar species, breeding in the extreme Arctic Regions of both hemispheres. Straggles irregularly southwards in winter into the temperate regions.

\section{GREAT SKUA. Stercorarius catarrhactes.}

Rare winter visitor, breeding on the Shetland Islands. North Atlautic species, breeding also on the laroes, Iceland, and probably on some of the subarctic American islands. Is not known to wander as far south as the Tropics in winter.

\section{POMARINE SKUA. Stercorarius pomarinus.}

Irregular winter visitor. Circumpolar species, breeding in the extreme north, and wandering southwards in winter, sometimes as far as the Tropics.

\section{RICHARDSON'S SKUA. Stercorarius richardsoni.}

Frequent winter visitor, breeding in the north of Scotland. Circumpolar species, breeding in the Arctic and Subarctic Regions. Winter range extending across the temperate regions to the Tropics.

\section{BUFFON'S SKUA. Stercorarius buffoni.}

Irregular winter visitor. Circumpolar species, breeding in the extreme north. Winter range extending far into the temperate regions, but not as far as the Tropics. 



\section{Suborder GRALL王.}

\section{Family GRUIDE.}

COMMON CRANE. Grus communis.

Rare winter visitor; bred in the fens three or four centurics ago. Breeds in Spain, Central Europe, Turkestan, and Siberia. Winters in North Africa and South Asia.

\section{DEMOISELLE! CRANE. Grus virgo.}

Accidental visitor; one British record (Orkneys). Breeds in Algeria, South Spain, the basins of the Black and Caspian Seas, South-west Siberia, Dauria, and East Mongolia. Winters in Central Africa and India.

\section{Family TURNICIDÆ.}

\section{ANDALUSIAN HEMIPODE. Turnix sylvatica.}

Supposed to be an accidental visitor ; three British records (Oxfordshire, Yorkshire), possibly of birds escaped from confinement. Resident in South Spain, South Portugal, and North-west Africa.

\section{Family PTEROCLID Æ.}

PALLAS'S SAND-GROUSE. Syrrhaptes paradoxus.

Accidental visitor; in 1863 and 1888 in great numbers. Breeds in Siberian Turkestan, Mongolia, and Dauria, migrating southwards in autumn from the coldest parts of its range.

\section{Suborder FULICARI E.}

\section{Family OTIDIDÆ.}

\section{GREAT BUSTARD. Otis tarda.}

Rare winter visitor; was a resident fifty years ago; unknown in Ireland. Breeds in Southern and Central Europe, Russian Turkestan, and Southwest Siberia. Migrates southwards in autumn from the coldest parts of its range. 

LITTLE BUSTARD. Otis tetrax.

Rare winter visitor. Breeds in South Europe, North Africa, Persia, Russian Turkestan, and South-west Siberia. Migrates in autumn from the coldest parts of its range to winter in Egypt and the valley of the Indus.

\section{MACQUEEN'S BUSTARD. Otis macqueeni.}

Accidental visitor; one British record (Lincolnshire). Breeds in Central Asia. Winters in South Persia, Baluchistan, Sind, and the Punjab.

\section{Family RALLID㤅.}

WATERHEN. Gallinula chloropus.

Common resident. Summer risitor to subaretic Europe and South Siberia. Resident in the tropical and subtropical parts of Africa, Europe, Asia, the Malay Archipelago, and America.

\section{C00T. Fulica atra.}

Common resident. Summer visitor to subarctic Europe and South Siberia. Resident in Central and Southern Europe, North Africa, South Asia, and Australia. Winter visitor to West and East Africa.

\section{PURPLE GALLINULE. Porphyrio cæruleus.}

Supposed to be an accidental visitor; six British records (four English, one Scotch, one Irish), possibly of escaped hirds. Resident in Italy, Spain, and Algeria.

\section{GREEN-BACKED GALLINULE. Porphyrio smaragdonotus.}

Supposed to be an accidental visitor; nine British records (six English, one Scotch, two Irish), possibly of escaped birds. Resident throughout Africa, except the north-west. 



\section{MARTINIQUE GALLINULE. Porphyrio martinicus.}

Supposed accidental visitor; one apparently authentic British record (Hampshire). Resident in tropical and subtropical America.

\section{WATER-RAIL. Rallus aquaticus.}

Resident. Summer visitor to subarctic Europe and Russian and Chinese Turkestan. Resident in South Europe and North Africa. Winter visitor to Asia Minor, Persia, and North-west India.

\section{CORN-CRAKE. Crex pratensis.}

Common summer visitor, a few remaining to winter. Summer visitor to Europe south of the Arctic Circle, South-west Siberia, Russian Turkestan, and Afghanistan. Resident in Algeria and Asia Minor. Winter visitor to Africa, south of the Sahara.

\section{SPOTTED CRAKE. Crex porzana.}

Rare summer visitor, a few remaining to winter. Breeds in Europe, North Africa, Turkestan, Sonth-west Siberia, and Persia. Migrates in autumn from the northern part of its range to winter in Egypt and India.

\section{LITTLE CRAKE. Crex parva,}

Rare spring and autumn migrant in England; accidental visitor to Scotland and Ireland. Summer visitor to Central Europe, Russian Turkestan, and Afghanistan. Resident in Algeria and South Europe. Winter visitor to Sind.

\section{BAILLON'S CRAKE. Crex bailloni.}

Very rare resident in England; accidental visitor to Scotland and Ireland. Summer visitor to subarctic Europe. Resident in South Europe, Africa, and Madagascar. Represented in East Asia by a nearly allied but distinct species.

\section{CAROLINA RAIL. Crex carolina.}

Accidental visitor, one British record (Berkshire). Breeds in subarctic America. Winters in the Southern States, Mexico, Central America, and the West Indies. 



\section{Suborder ANSERES.}

\section{Family ANATID正.}

MUTE SWAN. Cygnus olor.

Resident in a more or less domesticated state. Summer visitor to Central and Eastern Europe, Turkestan, and Mongolia; wintering on the shores of the Mediterranean and Caspian Seas.

\section{H00PER SWAN. Cygnus musicus.}

Winter visitor. Breeds in the Aretic Regions of the Old World from Iceland to Kamtschatka. Winters on the shores of the Mediterranean and Caspian Seas, and in Japan and North China.

\section{BEWICK'S SWAN. Cygnus bewicki.}

Winter visitor. Brecds in the Aretic Regions of East Russia and Siberia. Winters on the coasts of Japan and North China, and on the shores of the Caspian, and occasionally of the Mediterranean, Sea.

\section{AMERICAN SWAN. Cygnus americanus.}

Supposed accidental visitor; two somewhat doubtful records (Scotland). Breeds in the Arctic and Subarctic Regions of $\Lambda$ merica, wandering south in winter as far as the confines of the Tropics.

\section{LESSER SN0W-G00SE. Anser hyperboreus.}

Rare accidental visitor; only one or two apparently authentic records (Ireland). Breeds in the Aretic Regions of Western America, and probably in those of Eastern $\Lambda$ sia, wandering in winter to California and Japan. 



\section{GREY-LAG G00SE. Anser cinereus.}

Winter visitor, a few remaining to breed in Scotland. Breeds in temperate Europe and Asia as far east as Lake Baikal. Winters in South Europe, North-west India, and North China.

\section{BEAN-G00SE. Anser segetum.}

Winter visitor. Breeds in arctic Europe and Siberia. Winters in South Europe, China, and Japan. Eastern examples are generally larger than western ones.

\section{PINK-F00TED G00SE. Anser brachyrhynchus.}

Common winter visitor, but has only ouce been identified in Ireland. Breeds on Iceland and Spitzbergen, wandering south in autumn to the European coast.

\section{WHITE-FRONTED G00SE. Anser albifrons.}

Common winter visitor. Circumpolar species, breeding in the Aretic Regions of both continents, and wandering south in autumn to the confines of the Tropics.

\section{LESSER WHITE-FRONTED GO0SE. Anser minutus.}

Accidental visitor; two records of immature birds (Northumberland and Somerset). Breeds in arctic Europe and aretic Siberia, wandering south in autumn to the confines of the Tropics.

\section{BRENT G00SE. Bernicla brenta.}

Winter visitor. Breeds in Eastern America north of latitude $73^{\circ}$, Franz-Josef Land, Spitzbergen, Nova Zembla, and the Taimur Peninsula, wandering in winter almost to the confines of the Tropies. The white-bellied examples are supposed to breed in America. 

BERNACLE G00SE. Bernicla leucopsis.

Winter visitor. Supposed to breed in Greenland, Iceland, Spitzbergen, and Nova Zembla. In winter wander's southwards, but not as far as the Tropics.

\section{CANADA GO0SE. Bernicla canadensis.}

Possibly an accidental winter visitor, but has been kept in domestication for centuries. Breeds in arctic and subarctic Anerica, wandering southwards in winter as far as Mexico and the West Indies.

\section{RED-BREASTED G00SE. Bernicla ruficollis.}

Accidental winter visitor. Breeds above the limit of forest-growth in the valleys of the $\mathrm{Obb}$ and the Yenesci. Winters on the Caspion, and occasionally in the neighbouring countries.

\section{COMMON SHELDRAKE. Tadorna cornuta.}

Local resident. Breeds in the temperate parts of Europe and Asia, in the coldest parts of its range migrating southwards in winter to the confines of the Tropics.

\section{RUDDY SHELDRAKE. Tadorna rutila.}

Rare accidental visitor, many records being doubtless of escaped birds. Resident in South Europe. Breeds in South Siberia and Persia. Winters in China, Burma, and India.

\section{GADWALL. Anas strepera.}

Rare winter visitor, remaining to breed in a few protected localitics. Circumpolar species, breeding in the subaretic and subtropical, and wintering in the subtropical and tropical parts of the northern hemisphere. 



\section{PINTAIL. Anas acuta.}

Common winter visitor. Circumpolar species, breeding in the Arctic Regions, and in rare instances further south. Winters in the subtropical and tropical parts of the northern hemisphere.

\section{WIGE0N. Anas penelope.}

Common winter visitor, a very few remaining to breed in Scotland and Ireland. Breeds in the Aretic Regions of Europe and Asia, and occasionally further south. Winters in the temperate and tropical parts of the Old World north of the Equator.

\section{AMERICAN WIGEON. Anas americana,}

Supposed accidental visitor, none of the records (England and Ireland) being quite satisfactory. Breeds in the Aretic Regions of America, wintering in the Southern States, the West Indies, and Mexico.

\section{COMMON TEAL, Anas orecca.}

Common winter visitor, a considerable number remaining to breed. Breeds in the Aretic Regions of the Old World and occasionally further south. Wanders in winter almost as far south as the Equator.

\section{AMERICAN TEAL. Anas carolinensis.}

Accidental winter visitor; three records (Hants, Yorkshire, Devon). 13recds in the Aretic Regions of America, and occasionally further south, wandering in winter as far south as Central America and the West Indies.

\section{GARGANEY. Anas circia}

Spring and autumn migrant, a few remaining to breed. Breeds in sub. aretic Europe and Asia. Winters from the basin of the Mediterrancan across tropical Asia to the Philippines. 



\section{BLUE-WINGED TEAL. Anas discors.}

Supposed accidental winter visitor; one apparently authentic record (Dumfries). Breeds in subarctic and subtropical North America. Winters in subtropical and tropical North America.

SHOVELLER. Anas clypeata.

Winter visitor, some remaining to breed. Circumpolar species, breeding in the Aretic Regions and sparingly further south. Its wiuter range does not extend as far south as the Equator.

MALLARD. Anas boschas.

Common winter visitor, many remaining to breed. Circumpolar species, breeding in the Subaretic Regions of both continents and in some numbers further south. Its winter range does not quite reach the Equator.

\section{COMMON POCHARD. Fuligula ferina.}

Winter visitor, many remaining to brecd. Summer visitor to subaretic Europe and South Siberia as far cast as Lake Baikal. Winter visitor to South Europe, North Africa, Persia, India, China, and Japan.

RED-CRESTED POCHARD. Fuligula rufina.

Rare accidental winter visitor (about a score records). Resident in South Europe and North Africa. Summer visitor to Turkestan, wintering in India.

\section{WHITE-EYED POCHARD. Fuligula nyroca.}

Tare accidental winter visitor. Brecds in Europe south of the Baltic, North Africa, Turkestan, and Cashmere. In Central Europe and Turkestan migrates southwards in autumn to winter in Egypt and India. 

SCAUP. Fuligula marila.

Common winter visitor; said to have bred in Scotland. Circumpolar species, breeding in the Arctic Regions and wandering in autumn as far as the confines of the Tropics.

\section{TUFTED DUCK. Fuligula cristata.}

Winter visitor, many remaining to breed. Summer visitor to subarctic Europe and Asia. Winter visitor to South Europe, North Africa, South Asia, and Japan.

BUFFEL-HEADED DUCK. Fuligula albeola.

Accidental winter visitor (half a dozen records). Breeds in Arctic America, wintering in the United States, the West Indies, and on the coasts of Mexico.

GOLDEN-EYE، Fuligula clangula.

Winter visitor. Circumpolar species, breeding in the Arctic and Subarctic Regions of both continents. Winter range rarely reaching the Tropics.

HARLEQUIN DUCK. Fuligula histrionica.

Accidental winter visitor, two or three occurrences (Scotland and Yorkshire). Breeds in Arctic America, thence eastwards to Iceland, and westwards to Lake Baikal. Seldom wanders far south in winter.

LONG-TAILED DUCK. Fuligula glacialis.

Frequent winter visitor. Circumpolar species, breeding in the Arctic Regions, wandering southwards in winter, sometimes almost to the confines of the Tropics. 

COMMON SCOTER. Fuligula nigra.

Common winter visitor. Breeds in Iceland, and in the Aretic Regions of Europe and West Siberia. Wanders southwards in winter, but not as far as the Tropics.

VELVET SCOTER. Fuligula fusca.

Frequent winter visitor. Breeds in the Arctic Regions of Europe, and probably of West Siberia. Wanders southwards in wiuter, but not as far as the Tropics.

\section{SURF-SCOTER. Fuligula perspicillata.}

Rare winter visitor. Breeds in arctic and subarctic America, wandering southwards in winter, sometimes as far as the Tropics.

\section{COMMON EIDER. Somateria mollissima.}

Winter visitor, many remaining to breed on islands off the coasts of Scotland and North England. Breeds on the arctic and subarctic coasts on both shores of the Atlantic, as well as on the intermediate islands.

\section{KING EIDER. Somateria spectabilis.}

Rare visitor, principally in winter. Circumpolar species, breeding on the coasts of the Arctic Regions, and rarely wandering further south in winter.

\section{STELLER'S EIDER. Somateria stelleri.}

Accidental visitor; two British records (Norfolk and Yorkshire). Breeds on the arctic coasts of Europe and Asia, seldom wandering far in winter. 

GO0SANDER. Mergus merganser.

Winter visitor, occasionally breeding in Scotland. Breeds in arctic and subarctic Europe and Asia, migrating southwards in winter almost to the confines of the Tropics.

\section{RED-BREASTED MERGANSER. Mergus serrator.}

Winter visitor, many remaining to breed in Scotland and Ireland. Circumpolar species, breeding in the arctic and subarctic regions of both continents. Wanders southwards in winter, but not as far as the Tropics.

\section{HOODED MERGANSER. Mergus cucullatus.}

Accidental winter visitor to England and Ireland; half a dozen or more undoubted records. Breeds in arctic and subarctic America, wintering in the United States, Mexico, and the West Indies.

SMEW. Mergus albellus.

Rare winter visitor. Breeds in arctic and subarctic Europe and Asia. In winter it occasionally wanders as far as the confines of the Tropics.

\section{Family PHCENICOPTERIDÆ.}

\section{FLAMING0. Phœnicopterus roseus.}

Possibly an accidental winter visitor; two records of alleged wild birds (Staffordshire, Hampshire). Breeds in Central and North Africa, South Europe, and Persia, wintering in South and East Africa and in India. 



\section{Suborder ALC列.}

\section{Family ALCID屃.}

\section{RAZ0RBILL. Alca torda.}

Common resident. North Atlantic species, breeding from Nova Scotia, Grecnland, and Iceland to Scandinavia, the British Islands, and North France. Migrates in autumn from the coldest parts of its range as far as the confines of the Tropics.

\section{COMMON GUILLEMOT. Alca troile.}

Resident. Circumpolar species, divisible into several local races. 'Typical form breeds in the North Atlantic from Nora Scotia, South Greenland, South Iccland, and Bear Island to the coasts of Norway, the British Islands, and West Europe.

\section{COMMON GUILLEMOT. Alca troile.}

Resident. Circumpolar species, divisible into several local races. Typical form breeds in the North Atlantic from Nova Scotia, South Greenland, South Iceland, and Bear Island to the coasts of Norway, the British Islands, and West Europe.

\section{COMMON GUILLEM0T. Alca troile.}

Resident. Circumpolar species, divisible into several local races. Typical form brects in the North Atlantic from Nova Scotia, South Greenland, South Iccland, and Bcar Islaud to the coasts of Norway, the British Islands, and West Europe.

\section{COMMON GULLEMOT. Alca troile.}

Resident. Circumpolar species, divisible into several local races. 'Typical form breeds in the North Atlantic from Nova Scotia, South Greenland, South Iceland, and Bear Island to the coasts of Norway, the British Islands, and West Europe.

\section{COMMOIN GUILLEMOT. Alca troile.}

Resident. Circumpolar species, divisible into several local races. 'Typical form brects in the North Atlantic from Nova Scotia, South Greenland, South Iceland, and Bear Island to the coasts of Norway, the British Islands, and West Europe. 



\section{Suborder ALCÆ.}

\section{Family ALCID $Æ$.}

\section{RAZ0RBILL. Alca torda.}

Common resident. North Atlantic species, breeding from Nova Scotia, Greenland, and Iceland to Scandinavia, the British Islands, and North Hrance. Migrates in autumn from the coldest parts of its range as far as the confines of the Tropics.

\section{COMMON GUILLEMOT. Alca troile.}

Resident. Circumpolar species, divisible into several local races. Typical form breeds in the North Atlantic from Nova Scotia, South Greenland, South Iceland, and Bear Island to the coasts of Norway, the British Islands, and West Europe.

\section{COMMON GUILLEM0T. Alca troile.}

Resident. Circumpolar species, divisible into several local races. Typical form breeds in the North Atlantic from Nova Scotia, South Grecnlaud, South Iceland, and Bear Island to the coasts of Norway, the British Islands, and West Europe.

\section{COMMON GUILLEM0T. Alca troile.}

Resident. Circumpolar species, divisible into several local races. 'Typical form breeds in the North Atlantic from Nova Scotia, Sonth Greenland, South Iceland, and Bear Island to the coasts of Norway, the British Islands, and West Europe.

\section{COMMON GUILLEM0T. Alca troile.}

Resident. Circumpolar species, divisible into several local races. 'Typical form breeds in the North Atlantic from Nova Scotia, South Grcenland, South Iceland, and Bear Island to the coasts of Norway, the British Islands, and West Europe.

\section{COMMON GUILLEM0T. Alca troile.}

Resident. Circumpolar species, divisible into several local races. Typical form breeds in the North Atlantic from Nova Scotia, South Grecnland, South Icelaud, and Bear Island to the coasts of Norway, the British Islands, and West Europe. 



\section{BIOLOGIA CENTRALI-AMERICANA ; \\ $\mathrm{or}$,}

Contributions to the Knowledge of the Fauna and Flora of Mexico and Central America.

EDITED BY F. D. GODMAN AND O. SALVIN, F.F.R.S. A Prospectus will be sent on Application.

BIRDS OF DORSET.-A Contribution to the Natural History of the County. By J. C. Mansel-Pleydelt, B.A., F.L.S., F.G.S. In One Vol., 8vo, with Frontispiece and other illustrations, $7 s .6 d$.

BIRDS OF WILTSHIRE.-Comprising all the Periodical and Occasional Visitants as well as those which are indigenous to the County. By the Rev. A. C. Smitr, M.A. 8 vo, cloth, $10 s$.

BIRDS OF GUERNSEY, and the neighbouring Islands, Alderney, Sark, Jethou, Herm; being a small contribution to the Ornithology of the Channel Islands. By C. Suith. Post 8 ro, cloth, 6s. $6 d$.

BIRDS OF SUSSEX. By W. Borrer. With Coloured Plates, 8vo, cloth, $15 s$.

THE BIRDS OF DEVON. By W. S. M. D'URBAN, F.L.S., F.E.S., formerly Curator of the Albert Memorial Museum, Exeter, and the Rev. Murrat A. Mathew, M.A., F.L.S., Member of the British Ornithologists' Union. With Coloured Figures of rare Devonshire Birds, Illustrations of important Bird Stations, and Three Maps. Demy 8vo, cloth. Price $21 s$.

NESTS AND EGGS OF INDIAN BIRDS. By AltaN O. Hume, C.B. Second Edition, Edited and Revised by E. W. OAtes.

Portraits of A. O. Huine, T. C. Jerdon, Colonel Tickeld, Brian Hodgson, W. T. Blanford, R. G. Wardiaw Ramsay, Col. H. H. Godwin-Austen, E. Blyth, Arthur, Ninth Marquis of Tweeddale, W. E. Broeks, R. Bowdler Sharpe, and W. R. Davison. Medium 8vo, Three Vols., cloth. Price $\star^{2} 33$.

ARGENTINE ORNITHOLOGY : a Descriptive Catalogue of the Birds of the Argentine Republic. By P. L. Sclater, M.A., Ph.D., F.R.S., \&c. With Notes on their Habits by W. H. Hudson, C.M.Z.S., late of Buenos Ayres. With 20 Coloured Plates by J. G. Keulemans. In Two Vols., Royal 8vo. Price $£ 33 s$.

THE BIRDS OF THE SANDWICH ISLANDS. By ScoTt B. WrLSON, F.Z.S., F.R.G.S., assisted by A. H. Evans, M.A., F.Z.S. Parts I. to IV. ready, with 34 hand-coloured and 3 black Plates. Royal 4 to. To be completed in 5 Parts at 21 s, each.

ROUGH NOTES ON THE BIRDS OBSERVED DURING TWENTY-FIVE YEARS' SHOOTING AND COLLECTING IN THE BRITISH ISLANDS. By E. T. Воотн. Forming Three noble folio Volumes, containing 116 beautiful Coloured Plates. Price of the Three Volumes, unbound, $£ 21$; in halfmoroceo, gilt tops, $£ 25$.

INDEX GENERUM AVIUM. A List of the Genera and Subgenera of Birds. By F.H. WAterhouse, A.L.S., Librarian to the Zoological Society of London. Demy 8 ro, pp. 240, Price 12s. 6d. Indispensable to working Ornithologists.

A REVIEW OF RECENT ATTEMPTS TO CLASSIFY BIRDS. BY R. BOWDLER Sharpe, LL.D., F.L.S. Royal 8vo. Price 7s. 6 $c$.

CATALOGUE OF A COLLECTION OF BRITISH BIRDS formed by the late John HENRy GURNeY and his Son (compiled and drawn up by the latter), with the Localities, Sex, and State of Plumage. Small 8vo. With one Plate, post free, $1 s .3 d$.

NATURAL HISTORY OF THE CRANES. By E. BLYTH. Greatly enlarged, and reprinted, with numerous Illustrations. By W. B. TegetmeIER. Royal 8vo. Price 15 s. 


\section{HENRY SEEBOHM'S ORNITHOLOGICAL WORKS.}

\section{A HISTORY OF BRITISH BIRDS,}

WITH COLOURED ILLUSTRATIONS OF THEIR EGGS.

This fine Work forms Four Royal 8ro Volumes; Three of Text and One of Plates.

Price, in Parts, as issued, $£ 66 s$. In half-morocco, gilt tops, $\mathfrak{£ 7} 17 \mathrm{~s}$.

CATALOGUE OF THE PASSERIFORMES, OR PERCHING BIRDS IN THF

COLLECTION OF THE BRITISH MUSEUM.

CICHLOMORPHE: PART II,

Containing the Family Terdida (Warblers and Thrushrs).

8vo, with 18 coloured Plates and numerous Woodcuts, eloth, price $16 s$.

THE

GEOGRAPHICAL DISTRIBUTION OF THE CHARADRIIDA

OR PLOVERS, SANDPIPERS, SNIPES, AND THEIR ALLIES.

Royal 4to, cloth, with 21 hand-coloured Plates, $£ 5$ 5s. The same without Plates, $£ 212 s .6$

\section{CLASSIFICATION OF BIRDS;}

An attempt to Diagnose the Subclasses, Orders, Suborders, and some of the Families of existing Birds.

Royal Svo, cloth, price 3s. 6d.

THE BIRDS OF THE JAPANESE EMPIRE. With numerous woodcuts.

Royal 8vo, cloth, price $25 s$.

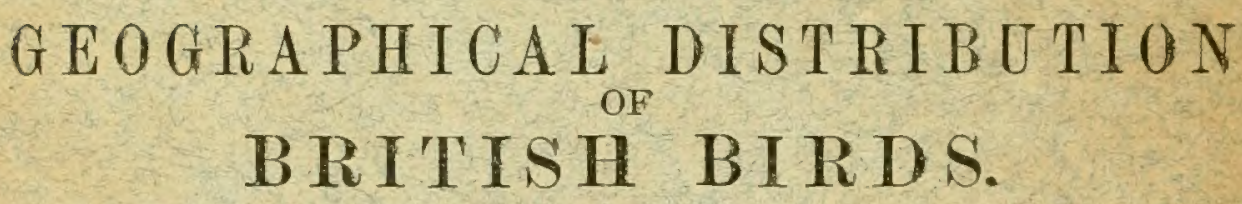

Royal $8 v 0,7 s .6 d$.

$\theta$

\section{H. E. DRESSER'S ORNITHOLOGICAL PUBLICATIOI}

A HISTORY OF THE BIRDS OF EUROPE (including all the Species inhab the Western Palæarctic Region). Royal 4to. 8vols. Half-morocco, tops. 50 guineas.

More than 600 hand-coloured plates by Josepu WoLF, J. G. KeUlenans, and E. Neahe forms seven thiek and one thin quarto volumes, with titlepages specially designed by JOSEPY T

A MONOGRAPH OF THE MEROPIDE, or Family of the Bee-eaters.

34 beautifully-coloured Plates. Imp. 4to. Half-morocco, gilt top. $£ 6$

EVERSMANN'S ADDENDA AD ZOOGRAPHIAM ROSSO-ASIATICAN exact copy of the Original, edited by H. E. Dresser. Sro. 6s.

A LIST OF EUROPEAN BIRDS, including all the Speeies found in the We Palæarctic Region. 8ro, 1 s. 

